Fall 11-19-2020

\title{
Nurse-Initiated Protocols for Chest Pain in the Emergency Department
}

\author{
Matthew Hodges \\ University of St. Augustine for Health Sciences, m.hodges@usa.edu
}

DOI: https://doi.org/10.46409/sr.DBAR8053

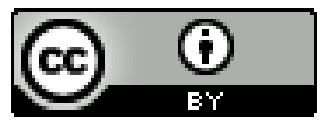

This work is licensed under a Creative Commons Attribution 4.0 License.

Follow this and additional works at: https://soar.usa.edu/scholprojects

Part of the Cardiovascular Diseases Commons, Critical Care Nursing Commons, and the Emergency Medicine Commons

\section{Recommended Citation}

Hodges, M. (2020). Nurse-Initiated Protocols for Chest Pain in the Emergency Department. [Doctoral project, University of St Augustine for Health Sciences]. SOAR @ USA: Student Scholarly Projects Collection. https://doi.org/10.46409/sr.DBAR8053

This Scholarly Project is brought to you for free and open access by the Student Research at SOAR @ USA. It has been accepted for inclusion in Student Scholarly Projects by an authorized administrator of SOAR @ USA. For more information, please contact soar@usa.edu, erobinson@usa.edu. 
Nurse-Initiated Protocols for Chest Pain in the Emergency Department

\author{
Matthew Hodges, MSN, RN, CEN \\ School of Nursing, University of St. Augustine for Health Sciences
}

This Manuscript Partially Fulfills the Requirements for the

Doctor of Nursing Practice Program and is Approved by:

Sarah M. I. Cartwright, DNP, MSN-PH, BAM, RN-BC, CAPA, FASPAN

Sandra Swearingen, $\mathrm{PhD}, \mathrm{RN}$

November 19, 2020 
University of St. Augustine for Health Sciences

DNP Scholarly Project

Signature Form

\begin{tabular}{|c|c|c|}
\hline $\begin{array}{l}\text { Student Last Name: } \\
\text { Hodges }\end{array}$ & $\begin{array}{l}\text { First Name: } \\
\text { M atthew }\end{array}$ & $\begin{array}{l}\text { Middle Initial: } \\
\text { W }\end{array}$ \\
\hline \multicolumn{3}{|l|}{ m-mail: } \\
\hline \multicolumn{3}{|c|}{$\begin{array}{l}\text { Title of DNP Project: } \\
\text { Nurse-Initiated Protocols for Chest Pain in the Emergency Department }\end{array}$} \\
\hline \multicolumn{3}{|c|}{$\begin{array}{c}\text { My signature confirms I have reviewed and approved this final written DNP Scholarly Project. } \\
\text { DocuSign electronic signature or wet signature required. }\end{array}$} \\
\hline Type Name in Blue Box Below & Signature & Date \\
\hline $\begin{array}{l}\text { DNP Project Primary Faculty: } \\
\text { Sarah M. I. Cartwright, DNP, MSN-PH, BAM, RN-BC, CAPA, FASPAN }\end{array}$ & 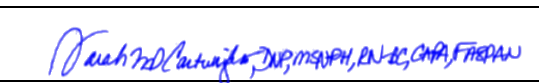 & $11 / 20 / 2020$ \\
\hline $\begin{array}{l}\text { DNP Project Preceptor: } \\
\text { Sandra Swearingen, PhD, RN }\end{array}$ & Shovearing & $11 / 23 / 2020$ \\
\hline DNP Project Preceptor: & & \\
\hline
\end{tabular}




\begin{abstract}
Practice Problem: Emergency department crowding inhibits the ability to provide safe patient care to chest pain patients and negatively impact patient outcomes. A Veteran Affairs emergency department has identified a similar concern and implemented a nurse-initiated protocol to decrease the length of stay and improve patient outcomes.

PICOT: This evidence-based practice (EBP) project was guided by the following PICOT question: In the emergency department (ED), how does a nurse-initiated protocol (NIP) for chest pain $(\mathrm{CP})$ patients compared to no protocol use influence length of stay (LOS) in the ED over 8 weeks?
\end{abstract}

Evidence: The reviewed literature supported the evidence of effective use of a nurse-initiated protocol in reducing the length of stay in the emergency department. Eleven articles met the inclusion criteria and were used for this literature review.

Intervention: The evidence-based nurse-initiated protocol is an intervention to provide objective clinical practice guidelines for chest pain patients resulting in improved earlier diagnostic results and decreased length of stay in the emergency department.

Outcome: Post-implementation conclusions revealed no reduction in length of stay after using the protocol but achieved a clinically significant decrease in the time of completion for 12-lead EKGs.

Conclusion: Staff education and the implementation of an evidence-based NIP for CP established positive outcomes on reducing EKG times. The results were also clinically significant to validate the implementation of nursing protocols in the ED for decreasing LOS and improving patient outcomes. 


\section{Nurse-Initiated Protocols for Chest Pain in the Emergency Department}

The development and implementation of a nurse-initiated protocol (NIP) for chest pain (CP) complaints in the emergency department (ED) should establish a reduced LOS for this patient population and improve patient flow. The key responsibility of any ED is to respond to patient emergencies while providing safe care to everyone (Burgess et al., 2018). ED overcrowding negatively impacts patient outcomes, confines treatment for time-sensitive conditions like sepsis or chest pain and can increase the likelihood of errors (Miake-Lye et al., 2017). Chest pain is the chief complaint about roughly 10 million ED visits each year in the United States and incurs an expense of nearly $\$ 10$ billion for acute coronary syndrome patients (Riley et al., 2017). Chest pain can also worsen patient morbidity and mortality (Long et al., 2017). The central aim of the project is to decrease LOS in the ED for CP patients.

Douma et al. (2016) demonstrate that nurse-driven protocols effectively address overcrowding and decrease the length of stay (LOS) in the ED. The Emergency Nurses Association (ENA) support triage protocols for expedited and improved patient care in the ED (ENA, 2015). Acute coronary syndrome (ACS) or myocardial infarction is diagnosed in a patient with fitting symptoms. The evaluation of CP patients involves determining whether they have experienced an acute myocardial infarction (AMI) (Andruchow et al., 2018). Diagnostic testing is used to verify the presence or absence of acute myocardial infarction (Andruchow et al., 2018).

\section{Significance of the Practice Problem}

Emergency Department (ED) crowding causes countless barriers, longer time-to-triage, and time-to-provider wait times. These longer times give accurate triage to prevent poor patient outcomes and reduce hospital liability (Reinhardt, 2017). The Veterans Affairs Medical Center 
(VAMC) deals with crowding and extended LOS issues daily. ED crowding has been a growing factor for nearly two decades in the United States and worldwide (Fay et al., 2018).

A before-and-after study performed in an academic ED of over 50,000 annual visits studied nursing strategies for avoiding and minimizing crowding in the ED while improving patient outcomes and ED LOS (Ro et al., 2015). Triage-based orders followed with timely clinical treatment found a significant decrease in ED LOS (Ro et al., 2015). Nursing roles and changes in care models help meet patient and department needs and successfully address challenges with congestion and extended LOS in the ED (Elder et al., 2015).

Morley et al. (2018) state when the ED is under stress from crowding, patients with urgent clinical needs, such as cardiac issues or severe pain, do not always receive appropriate, timely care. Another review proposed nurse-initiated protocols (NIP) to reduce ED LOS and overcrowding, especially when radiology orders are needed (Burgess et al., 2018). Implementation of nurse-initiated protocols shows expedited diagnostic patient care before a patient-provider interaction (Pierce \& Gromley, 2016).

Multiple ED processes are implemented across the country to target input, throughput, and output factors to increase ED efficiency. Standing triage orders demonstrate one approach that targets the issues (Burgess et al., 2018). The standing orders are utilized for specific patient complaints or conditions and applied as a strategy to improve ED efficiency (Hwang et al., 2016). As an ED observes increased demand alongside the constrained supply of ED resources, there are longer patient wait times and increased ED LOS (Burgess \& Kynoch, 2017). Nurseinitiated protocols are considered a viable option to improve patient care outcomes in busy EDs (Rosenberg, 2016). Chest pain patients need attention with key diagnostic elements before admission or clearance for discharge can be implemented. An effective nurse protocol must 
include every stakeholder and close the gap between research and clinical practice (Kocher, 2017).

Decreasing LOS is a nationally recognized metric for efficiency and is vital in ED flow improvement (Douma et al., 2016). In a prospective, randomized controlled trial (RCT), over one-year, a tertiary teaching facility showed triage nurse-initiated radiographs reduced median ED LOS by 20 minutes (Lee et al., 2016). A prospective, observational study compared to three phases showed a LOS reduction for patients requiring diagnostic lab tests. Introducing point-ofcare testing (POCT) decreased LOS in ambulatory patient populations by 20-35

minutes (Kankaanpaa et al., 2016). Within the VAMC facilities, when these improvements were collectively calculated, as a percentage comparative to baseline LOS, enhancements typically ranged between 5\% and 20\% (U.S. Department of Veterans Affairs [VA], n.d.). Low acuity patient needs, and nurse-initiated interventions had the highest occurrence of studies that produced a reduced LOS greater than 30\% (Miake-Lye et al., 2017). It is crucial to have a wellorganized and evidence-based chest pain protocol in the ED to avoid adverse outcomes related to any delays in the identification and treatment of ACS or MI diagnosis (Bunch et al., 2016).

\section{PICOT Question}

In the emergency department (ED), how does a nurse-initiated protocol (NIP) for chest pain $(\mathrm{CP})$ patients compared to no protocol use influence length of stay (LOS) in the ED over 8 weeks?

\section{Population}

Patients presenting to the ED with complaints of $\mathrm{CP}$ was the focused population in this project due to the associated risks in these patients. Higher mortality rates, higher rates of cardiovascular complications in patients with chest pain, and low-grade patient experiences are 
documented outcomes (Warner et al., 2015). Factors contributing to the surge in ED visits include an aging population, limited access to medical care, and a rising trend toward utilizing the emergency department for non-emergency care (Pierce \& Gromley, 2016). Patients identified with urgent clinical needs, such as cardiac issues or severe pain, need to receive appropriate, timely care (Morley et al., 2018).

\section{Intervention}

Protocols are facility-based guidelines developed for specific disease conditions or chief complaints (ENA, 2015). These allow a nurse to begin diagnostic tests for the patient before being evaluated by a provider (Stauber, 2013). The CP NIP intervention was created from evidence in the literature and established on a CP complaint-specific protocol approved by the ED providers, the ED Medical Director, and the facility Chief Medical Officer (CMO). Classes for electronic health record (EHR) ordering were provided to the nursing staff before implementation to familiarize personnel with the protocol order set. The NIP order set was built into the EHR and categorized by the patient complaints about ease of use. Evidence suggests a direct link between triage nurses in the ED and the implementation of diagnostic protocols with specific patient populations resulting in improved, early diagnostic results and overall decreasing LOS in the ED (Burgess et al., 2018). Various articles revealed increases in productivity outcomes by rearranging the use of current resources (Miake-Lye et al., 2017). Nurse-initiated protocols are standing orders and considered viable options to improve patient care outcomes in busy EDs (Rosenberg, 2016). Standing orders come from consensus and clinical practice guidelines for specific patient complaints or conditions; they are applied as a strategy to improve ED efficiency (Hwang et al., 2016). Implementation of a NIP for CP is within the locus of control as a registered nurse. 


\section{Comparison}

A pre and post assessment was completed in the ED to compare changes in LOS after implementing CP nurse-initiated protocols. The local emergency department did not use nurseinitiated protocols at the beginning of the project. The plan, do, study, act (PDSA) improvement method offered the framework to identify existing LOS in the ED flow process and summative evaluation after completing nurse-driven protocol performance improvement interventions (Reinhardt, 2017). Total LOS in the ED was assessed in retrospective CP patient populations utilizing current standard treatment processes and compared to those receiving the nurse-initiated protocol.

\section{Outcome}

Evidence suggests that utilizing nurse-initiated protocols in the ED can decrease LOS and positively impact costs to the organization (Miake-Lye et al., 2017). The current LOS for ED CP patients was greater than 5 hours. The decreased LOS of $<240$ minutes with this specific population after 8 weeks of CP NIP implementation was anticipated. Within VAMC facilities, when these improvements were collectively calculated, as a percentage comparative to baseline LOS, enhancements typically ranged between 5\% and 20\% (Miake-Lye et al., 2017).

A quantitative data collection was utilized to validate the correlation between the given variables and outcomes (Choy, 2014). The Strategic Analytics for Improvement and Learning (SAIL) Value Model is a system used within all Veterans Affairs facilities for data collection and quality improvement project analysis (VA, n.d.). A SAIL team member was utilized for expertise in data collection and their ability to summarize LOS for pre and post utilization of the protocol. 


\section{Timeframe}

The project duration was eight weeks. The project commenced after the University's Evidence-Based Practice Review Council (EPRC) and the facility's affiliate Institutional Review Board (IRB), and the Research and Development Committee approved the project. A before and after EHR review included all patients presenting to the ED with CP complaints eight weeks before and eight weeks after implementing the NIP. Total LOS in each group was calculated for the project, including a post-implementation assessment, and took place in the local VAMC ED.

\section{Evidence-Based Practice Framework \& Change Theory}

Some organizations currently use rapid assessment pathways or protocols for ACS/CP patients in the ED (Bunch et al., 2016). Protocols provide standardization in practice and reduce unnecessary resources with the final goal of improved care quality and reduced expenses (Bunch et al., 2016). Literature supports utilizing nurse-initiated protocols in the ED to decrease LOS and positively impact costs to the organization (Miake-Lye et al., 2017). Clinical staff in the ED can utilize the PDSA model (Reinhardt, 2017), and Lewin's theory on change will identify areas for improvement (Hussain et al., 2018).

Lewin's theory of change was the theoretical model to support this project. This model has been effective in producing a change in various organizations (Lewin, 1947). It emphasizes the importance of the formation, motivation, and maintenance of social groups (Lewin, 1947). There are three steps in the sequence of change, including unfreezing, moving, and refreezing. Unfreezing involves fostering buy-in from stakeholders in the organization that recognize and appreciate the necessity for change (Hussain et al., 2018). The unfreezing process helps abandon old behaviors and endorses the successful acquisition of new behaviors. The moving stage identifies what should be changed and develops an implementation strategy to 
resonate with change goals (Hussain et al., 2018). Refreezing then provides group steadiness at a new quasi-stationary equilibrium. It requires equivalence between the change process's behaviors, the working environment, and overall group dynamics (Hussain et al., 2018).

\section{Improvement Model}

A PDSA improvement model guided the study and offered the framework to identify existing LOS in the ED flow process. The model guided adjustments during nurse-driven protocol performance improvement interventions (Reinhardt, 2017). The PDSA model is widely used in evidence-based project (EBP) improvement to seek out process weaknesses and permit strategies for resolving weaknesses (Knudsen et al., 2019). The PDSA model and Lewin's change theory were excellent in guiding the EBP project involving the CP NIP in the ED.

\section{Evidence Search Strategy}

The initial electronic search included CINAHL Complete, ScienceDirect, PubMed, and EBSCOhost and the basic search began with no additional filters using "nurse-initiated protocols in triage" for the search criteria. This search yielded 1252 journal articles from over the last two decades. Google Scholar was used briefly and included multiple articles in a non-filtered range. A brief hand search using the bibliography of one of the research articles in the Veterans Affairs local facility library did yield an additional qualified original research article for inclusion. Exclusions involved articles that were not available as a full document or required a request for the article, articles that fell outside the 2014 to 2019 date range, and articles where authors did not have clear results. Articles for inclusion were full-text articles, qualitative or quantitative study methods, and addressed chest pain order sets or protocols, nurse-initiated, and length of stay in the emergency department. A complete representation of exclusion and inclusion criteria is listed in Figure 1. 


\section{Evidence Search Results and Evaluation}

The original search included 1252 articles. Applying filters using the Boolean Operators, including "AND" and "OR" to form relevant statements that included decreased length of stay, chest pain, nursing protocols and emergency department narrowed the results to 252 citations and articles. Medical Subject Headings (MeSH) were utilized in the PubMed database to narrow the publications with (triage OR triage AND nurses OR nurse AND initiated AND chest pain protocol). Comparative words (throughput) and (interventions) were keywords also included in the searches and narrowed results to 79 citations and articles. Inclusion timeframe limits of 2014 through 2019 narrowed the results. The results from the inclusion and exclusion criteria brought the results to 11 articles.

The utilization of the John Hopkins Nursing Evidence-Based Practice (JHNEBP) grading tool provided label recommendations in the clinical review articles (John Hopkins University, n.d.). Articles comprised various methodological designs ranging from a prospective, retrospective, quasi-experimental, case-control, pragmatic randomized, systematic review, and descriptive model. These supporting resources will improve the foundation for a clinically based project. The literature yielded 11 qualifying articles for inclusion based on the JHNEBP tool ranging from level I A to level V A for project use. The search results showing the study's strength can be found in the Summary of Evidence in Appendix A and the Systematic Review summary in Appendix B. Figure 2, a Preferred Reporting Items for Systematic Reviews and Meta-Analysis (PRISMA), summarizes the results.

\section{Themes from the Evidence}

The literature review disclosed several mutual themes. During the article evaluation, literature synthesis found reliable, evidence-based support for decreasing LOS in the ED for CP 
patients, including triage nurse orders, early EKG times, earlier provider to patient contact, and improved outcomes. Each theme supports a quality change for decreasing LOS in the ED for CP patients.

\section{Triage Nurse Orders}

Evidence from the literature demonstrates opportunities for implementing a specific nurse-initiated chest pain protocol to decrease LOS in the ED. Standing triage orders originated from consensus statements and clinical practice guidelines for specific patient complaints or conditions and were applied in the ED as a strategy to improve efficiency (Hwang et al., 2016). Several studies identify improved timeliness of care for patients leading to reduced LOS with NIP use (Burgess \& Kynoch, 2017; Douma et al., 2016; Ro et al., 2015). Bunch et al. (2016) indicated a LOS reduction for CP patients requiring diagnostic lab tests, and Andruchow et al., (2018) suggest starting approved protocols before a provider sees the patient. When NIP processes are initiated, diagnostic results are finished sooner and disposition changes are improved (Hwang et al., 2016). Using a standardized NIP for CP can decrease LOS for CP patients in the ED (Baugh et al., 2016).

\section{EKG Completion}

Early completion of an EKG is essential for diagnosing ST-segment elevation myocardial infarction (STEMI), and EKG findings within 10 minutes of ED arrival are critical for positive outcomes (Yiadom, et al., 2017). EKG acquisition times found in the HEART study showed expedited patient care among intermediate and low risk $\mathrm{CP}$ patient populations while decreasing LOS (Baugh et al., 2016; Hwang et al., 2016). Safely determining the acuity of CP patients can also lead to early discharge among low-risk populations (Douma, et al., 2016; Mahler et al., 2018) 


\section{Early Physician Times}

A large, 5-month study showed a reduction in physician-to-disposition time by $16.9 \%$ with the implementation of NIP standing orders (Hwang, et al., 2016). NIP implementation demonstrated accelerated diagnostic patient care before a patient-provider interaction (Pierce \& Gromley, 2016). Additional evidence shows the benefits of implementing a chest pain protocol in the ED include improved throughput times due to earlier provider evaluations (Bunch et al., 2016).

\section{Improved Outcomes}

Evidence from the literature disclosed improved outcomes among CP patients in the ED with NIP implementation during the ED visit. Douma et al. (2016) provide indirect support for the use of NIP for CP patients for improving outcomes (Baugh et al., 2016). The use of standing orders or NIP for ED patient assessment for CP reduced LOS while improving safe discharges to home from $8.3 \%$ to $18.4 \%$ (Than \& Pickering, 2018). Evidence supports NIP use for improved patient outcomes in the ED (Burgess et al., 2018; Douma et al., 2016).

\section{Practice Recommendations}

Decreasing the LOS of CP patients in the ED using a NIP was the project's specific aim. Evidence from a literature review indicates a direct link with triage nurses in the ED and implementation of diagnostic protocols resulting in improved early diagnostic results and overall decreasing LOS in the ED (Burgess et al., 2018; Burgess \& Kynoch, 2017; Douma et al., 2016). ED crowding has resulted in countless barriers, longer time-to-triage, and time-to-provider wait times, consequently making accurate triage more critical than ever before to avoid poor patient outcomes and hospital liability (Reinhardt, 2017). 
Morley et al. (2018) noted when the ED is under stress from crowding, patients identified with urgent clinical needs, such as cardiac issues or severe pain, still need appropriate, timely care. Evidence suggests that utilizing nurse-initiated protocols in the ED can decrease LOS and positively impact costs to the organization (Miake-Lye et al., 2017). Implementing nurseinitiated protocols can expedite diagnostic patient care before a patient-provider interaction (Pierce \& Gromley, 2016). Based on the findings, the EBP recommendation for change decreased LOS by implementing the NIP for CP patients. Expected outcomes included the specific NIP for patients presenting to the ED with CP for improved time to test and decreased LOS in the ED. (Burgess \& Kynoch, 2017; Douma et al., 2016; Ro et al., 2015). Nursing roles and changes in care models help patient and department essentials successfully address congestion and extended LOS in the ED (Elder et al., 2015).

\section{Project Setting}

The project setting was a 16-bed ED in a Veterans Affairs ED in Georgia. The acute hospital's average daily census fluctuates between 75 and 85 percent total capacity with occasional critical care diversions due to total occupancy in ICU (VA, 2019). The ED is operational 24 hours a day, seven days a week. Staffing includes the registered nurse (RN) charge nurse, RN in Nurse First registration, a dedicated RN in triage, an Intermediate Care Technician (ICT) to assist with tasks, and a minimum of 4 additional RN's in a four patient per nurse assignment matrix. Additional support staff includes pharmacy, housekeeping, facility management, radiology, and lab personnel.

\section{Organizational Structure}

The VA Medical Center is a two-division medical center with three Community Based Outpatient Clinics (CBOC) (VA, 2019). The downtown division includes 156 acute and 20 
intensive care unit (ICU) beds in their medical-surgical facility. The hospital also contains an invasive cardiology suite with two operational cardiac catheterization laboratories. The downtown division includes the ED, acute medicine, and the Spinal Cord Injury Unit. The Uptown Division is located three miles away and serves inpatient and outpatient psychiatry, primary care, nursing home, and rehabilitation medicine (VA, 2019). The facility is part of Veterans Integrated Service Network (VISN) 7, located in Atlanta and associated with seven other medical facilities located in Alabama, Georgia, and South Carolina (VA, 2019).

\section{Organizational Culture}

The VA's organizational core values are Integrity, Commitment, Advocacy, Respect, and Excellence (I CARE) (VA, 2019). They define the essence of the VA, the culture, and cultivate everyone's actions throughout the VA (VA, 2019). The values foundationally serve to accomplish the mission, "To care for him who shall have borne the battle, and for his widow, and his orphan" (VA, 2019). Both the vision and mission play a critical role in supporting and honoring the men and women who have served our Nation (VA, 2019).

\section{Organizational Need}

The ED provider and patient's current practice depends on an initial face-to-face interaction before receiving and starting the diagnostic assessment. There were no current, written guidelines or protocols for nursing staff to follow to address the diagnostic requirements of any patient population. Current historical data reflects a lack of standardized processes in diagnostic assessments leading to extended LOS at $\geq 6$ hours for many acutely ill patients and delays for disposition to discharge or admission (W. May, personal communication, March 5, 2020). Due to the findings, the recommendation for EBP improvement included an evidencebased NIP for CP patient populations in the ED to decrease LOS. 


\section{Stakeholders}

The key stakeholders interested in decreasing LOS for CP patients included the ED Medical Director and Pentad leadership, including the Director, Associate Director, Assistant Director, Associate Director of Patient Care Services, and the Medical Director. Other crucial stakeholders were the patient and family members, ED clinical staff, and ancillary support staff. An interdisciplinary team approach of ED providers, clinical staff, and supporting ancillary departments, including but not limited to laboratory, radiology, and inpatient providers and nurses, was used to guide the success. Additionally, each shift's dedicated triage nurse improved nurse-initiated protocols' objective implementation and expedited diagnostic patient care before a patient-provider interaction (Pierce \& Gromley, 2016). Interprofessional collaboration is vital to show decreased LOS for CP patients in the ED.

\section{Strengths, Weaknesses, Opportunities, and Threat (SWOT) Analysis}

A SWOT analysis was completed to assess and mitigate potential issues that may impair success (Shahmoradi et al., 2017). Figure 3 outlines concerns noted in the SWOT analysis involving NIP for CP in the ED in our local facility. Key strengths were numerous. They included leader support, teamwork in the ED, and clinical judgment skills. ED crowding, current throughput, possible order duplication, and staffing shortage encompassed the weaknesses. Opportunities included ED Clinical Nurse Leader growth and support, professional collaboration, and actively empowering nursing staff to activate the protocols. Threats to success were mostly related to individual clinical assessment to qualify a patient for NIP use, staff resistance to change, and human bias. Appropriate education alleviated most of the concerns found in the analysis. 


\section{Project Overview}

The vision, mission, and objectives of the evidence-based project provided transparency to its purpose and goal. Mission statements define the business's purposes, while the vision statement described the projects anticipated goals and endpoints (Meyer, 2019). The primary objective was to successfully implement a CP NIP in the ED to decrease time to diagnostic tests and decrease LOS. After implementation, all ED nurses understood the orders and articulated benefits and properly applied them. The NIP orders permitted triage nurses to deliver earlier treatment and obtain diagnostic data on patients before a provider seeing the patient (Miake-Lye et al., 2017).

\section{Project Vision and Mission}

The vision supported the project's objective to reduce the LOS of CP patients presenting to the ED from the current LOS to $\leq 240$ minutes. Decreasing LOS in this EBP project should improve patient outcomes and decrease crowding in the ED (Burgess \& Kynoch, 2017; Douma et al., 2016). The anticipated decrease in LOS from the NIP for CP blended and supported the VA values by caring for the patients with I-CARE principles.

\section{Objectives}

The project's objective in decreasing LOS for CP patients is a nationally accepted quality metric for patient care in the ED (Baugh, et al., 2016; Higginson, et al., 2017). The current ED LOS for CP patient admissions is $>300$ minutes. The project's primary objective was providing earlier time to tests and effectively decreasing LOS by $20 \%$ to $\leq 240$ minutes.

\section{Short- and Long-Term Goals}

Short-term goals for this project focused on stakeholder support through education, understanding, and support of the CP NIP. In addition to the primary project objective discussed 
above, a second short-term goal within the first 30 days was to achieve essential stakeholder buyin and successful implementation of the CP NIP evidenced by $\geq 90 \%$ use for appropriate patients. These goals were assessed with a $100 \%$ audit involving CP patients seen in the ED after NIP implementation and completed by the project manager.

The primary long-term goal, after the project, included positive results validating a reduction in LOS for chest pain patients in the ED. Nurse-initiated protocol sustainability was evidenced and endorsed as the standardized EBP clinical practice in triage for CP patients. Ongoing clinical education will be done for new staff to ensure a consistent and sustainable NIP approach. Chart reviews were beneficial to demonstrate whether NIP interventions were utilized, improved time to test, or decreased LOS in the ED.

\section{Barriers and Unintended Consequences}

Identifying and correcting challenges in the EBP project in a suitable manner was vital for success. Barriers to success included a lack of compliance with NIP use by staff nurses. Physicians did not complete their education before implementation, and the new contract providers did not support protocol use. Unintended consequences developed from fragmented communication patterns between providers and clinical staff using the CP NIP and from COVID-19 related patient care restrictions. Triage nurses sometimes viewed the NIP as added work in triage related to more documentation and time-consuming tasks.

Identifying staff that completed the pre-implementation education and demonstrated understanding of the protocol through a return demonstration served as subject matter experts. They assisted staff nurses that had not completed the educational module or did not understand the NIP. Stratification of time variables and other changes were evaluated weekly and were essential elements of driving success in the intervention. Techniques to curtail any unintended 
effects or limitations included constant education to the clinical staff with ongoing encouragement and clinical support during the project. The objective order set outlining the specific diagnostic needs for CP patient populations standardized the NIP process.

\section{Project Plan}

For this project, assessments before and after implementing the NIP were done to compare LOS changes in the ED for patients presenting with CP. A chart review using the Computerized Patient Record System (CPRS) compared LOS after implementing nurse-driven protocols. Total LOS in the ED was assessed in retrospective patient populations compared to those receiving the nurse-driven protocols. The goal focused on decreasing ED LOS for CP patients to $\leq 240$ minutes. The current LOS in the ED is $\geq 300$ minutes with a standard approach of receiving diagnostic orders after being seen by a provider. The project used Lewin's Change Theory in conjunction with the PDSA practice model to implement EBP change.

\section{Lewin's Change Theory}

Lewin's model involves unfreezing, moving, and refreezing to promote change (Hussain et al., 2018). Unfreezing identified the issue, extended LOS for CP patients in the ED, and considered benefits from the change. Receiving support from stakeholders reinforced the likelihood of success in the need for change (Hussain et al., 2018). Next, the implementation of the NIP formulated the moving step of Lewin's theory and permitted the ED to start the change, measure progress, and evaluate constructive improvements (Hussain et al., 2018). Finally, in the third step of Lewin's change theory, refreezing occurred (Hussain et al., 2018). This step transpired when the data analysis demonstrated positive impacts on the clinical practice and provided possibilities for a sustainable EBP improvement to continue as a daily practice for ED clinical staff to use NIP for CP patients. 


\section{Intervention using the PDSA Model}

Department and hospital administration recognized the extended LOS for patients in the emergency department and supported the EBP project for change within the organization. The PDSA project plan guided opportunities for decreasing the LOS in the ED by using a NIP for CP during the 8-week project. Pre- and post-implementation EHR reviews covered patients presenting to the ED with CP complaints and improvements in LOS were evaluated. The project plan involved education for the clinical staff, providers, and other essential interdisciplinary members; then, the project began implementation of the NIP. The NIP's effectiveness included the study of LOS data and produce recommendations from the findings. Ongoing adjustments were considered throughout the project as reassessments and changes offered a better process for sustainable EBP project improvement.

Ongoing assessments for NIP success helped determine any need for modifying the process. Variables included EKG times, provider to patient contact, staff compliance using the NIP, and improved LOS outcomes while the patient is physically in the ED. The Fishbone Root

Cause Analysis tool, as seen in Figure 4, provided an assessment of potential factors that limited, inhibited, and negatively impacted NIP implementation in the ED. These included management, processes, environment, human factors, and resources. This list is not comprehensive yet demonstrated essential areas for consideration.

\section{Project Steps}

Leadership in the ED and facility administration supported the project to decrease LOS and recognized the project as a critical EBP project for the organization. The project began with the clinical staff and provider education in CP NIP implementation and supported the PDSA model phase by completing the planned change (Sylvia \& Terhaar, 2018). The Donna Wright 
model provided the structure for the educational requirements. The Donna Wright model is lateral education with three main principles: 1) competencies are collaborative, 2) learners are the core of the competency process, and 3) validation techniques evaluate three common domains: technical, critical thinking, and interpersonal skills (Wright, 2005). Chest pain was clinically defined and taught during education. For this project, $\mathrm{CP}$ was defined with symptoms that may include chest pain ranging from mild to severe, described as aching, sharp, tingling, burning, heavy, squeezing, heartburn, or tight. Patients may complain of lightheadedness, palpitations, diaphoresis, shortness of breath, nausea, indigestion, anxiety, restlessness, denial, or depression (Kocher, 2017). The detailed steps for implementing the project included:

1. Approval of an evidence-based NIP to meet ENA guidelines; obtained from the ED Medical Director and CMO.

2. Clinical staff education involving NIP use guidelines and steps for applying CP NIP in triage; with Donna Wright's model, education champions helped maintain the competency of NIP use.

3. The Clinical Applications Coordinator (Information Technology) uploaded the NIP order set and completed the test environment evaluations for accurate use before the go-live use in triage.

4. Implementing CP NIP in July 2020; included labs (I-Stat troponin, CBC, CMP, CKMB/CK, urine HCG for females of childbearing age), 12-lead EKG, supplemental oxygen, starting a peripheral IV site, and CXR.

5. Data collection and use of PDSA.

6. Data analysis with IBM SPSS, Microsoft Excel, and project dissemination. 
A detailed timeline chart for the project can be seen in Appendix $\mathrm{C}$ and demonstrates a summary and schedule for the EBP change process.

\section{Protocol Use}

The ENA encourages triage protocols for expedited and better-quality patient care in the ED (ENA, 2015). The project utilized an order set endorsed by the project stakeholders and developed by the ED Medical Director, an emergency medicine board-certified and clinically experienced physician. All essential stakeholders, including ED clinical nurses, department nurse leadership, and the ED unit practice council (UPC), reviewed the protocol to confirm the order set as evidence-based and supports best clinical practices for chest pain. After final approval by the medical center Chief of Staff, the project manager and facility nurse educators facilitated NIP awareness and education. The ED medical director completed physician education. The computerized, chest pain nurse-initiated protocol order set is shown in Appendix D. The NIP ENA endorsed and facility approved computer-based order set was uploaded by the Clinical Applications Coordinator (CAC) for use in CPRS. The NIP is embedded in the active emergency department nursing order sets. The CAC confirmed initial trial testing of the NIP order set in the test environment to safeguard against improper real-time errors.

\section{Budget and Resource Needs}

The ED clinical staff, supported by the interprofessional stakeholders, aided using the NIP intervention for this project. Educators provided supplementary needs for training in the facility. The budget required for the project was limited and related mostly to one hour's clinical staff education class. The cost of training 36 nurses with an average hourly rate of $\$ 35.00$ is a total of $\$ 1260$. Approval for this expense came from nursing leadership. A meeting with organizational leadership provided the benefits of reducing LOS, improved outcomes, patient 
satisfaction, and expense justification. Estimated annual savings with a $20 \%$ reduction in LOS among CP patients is $\$ 90,120.00$. The details involving financial costs and potential savings involved in the project are revealed in Table 1. The CAC handled information technology responsibilities under regular functional duties with no additional expense allocations required during the project. No extra expenditures were predicted from the clinical staff workload since all required activities were incorporated into the involved personnel's daily nursing responsibilities.

\section{Evaluation Results}

The project evaluation measured changes seen in LOS in the ED after eight weeks of NIP implementation. Departmental impacts, goal outcomes, and objectives were evaluated. An analysis of pre and post NIP implementation determined the reduction in ED LOS among CP patients during the project. The selection of $\mathrm{CP}$ patients was reviewed to ensure data reliability, objective measures, and standardized collection tools. EHR reviews included patients presenting to the $\mathrm{ED}$ with $\mathrm{CP}$ complaints during the project. Formative evaluations were completed during the project, and summative evaluations were finalized after the project (Sylvia \& Terhaar, 2018).

There was a reliable association between patient outcomes and ED LOS, including quality-of-care (Chang et al., 2017). Time from patient registration to disposition i.e., a discharge home, admission, or transfer, is the ED's defined LOS. The LOS of a patient in the ED was the primary element of the project, and the time to test is critical. A decreased LOS can positively impact patient outcomes with increased efficacy and effectiveness in patient care delivery (Fay et al., 2018). Based on this, practice changes from implementing a NIP for CP should provide: (1) 
expedited triage times, (2) EKG completion in $\leq 10$ minutes, (3) improved provider evaluation from early completion of diagnostic tests, and (4) decreased overall LOS in the ED.

\section{Data Collection Details}

Throughout the project's course, all patients meeting the nurse-driven protocol implementation criteria were tracked and trended by the project manager. The collection phase answered and calculated the measures associated with the PICOT. Outcome measures were collected and included: (1) time to complete a 12-lead EKG, and (2) total LOS in the ED. Additional summative data analyzed in the project included:

1. percentage of staff completing the NIP education,

2. staff satisfaction using NIP, and

3. the financial impact on the ED.

Data collected during the project was nominal for each of the outcome measures evaluated. The data collection tool for data analysis is included in Appendix E.

\section{Types of Measures}

In all EBP projects, measurements quantify the project results, and it is vital to have outcome measures, process measures, and balance measures (Institute for Healthcare Improvement [IHI], 2020). Accurate measures provide information to facilitate quality changes in healthcare practice (IHI, 2020). Table 2 summarizes details for each category of measure for the project with the type of statistical test used for each measure.

\section{Outcome Measures}

The primary outcome measure for this project was ED LOS in pre- and postimplementation categories. Secondary outcome measures included time to triage and time from registration to completion of a 12-lead EKG. Outcomes are resultant from the project PICOT and 
demarcate project accomplishment. The project manager had access to the CPRS EHR to obtain this information. A weekly review of the data was shared with the project team and adjustments made when necessary.

\section{Process Measures}

Process measures are steps that help lead the project to the desired outcome (IHI, 2020). For this project, process measures included the CP NIP implementation and the percentage of staff that complete the NIP education before implementation. The process measure for staff education was evaluated with the percentage of the staff that completed the education before the go live date for the protocol. Competency scores from the Donna Wright model of education identified champion staff that can reinforce the NIP process during the project timeframe (Wright, 2005).

\section{Balancing Measures}

A balancing measure evaluates if any change introduced to improve one part of the system produces a new issue or concern in other areas (IHI, 2020). The project's balancing measure was the staff percentage to find satisfaction with using the CP NIP during the project. The project manager assessed staff satisfaction through one-on-one staff conversations and observing the project progress. Staff satisfaction was measured at the end of the project with a simple survey.

\section{Financial Measures}

Direct and indirect expenses related to a project are the financial measures (IHI, 2020). They help determine any budgetary requirements for project success and will be approved by the organization before implementation. Financial measures included the cost of training the clinical 
staff during a 1-hour class on the needs, reasons for use, and the process of utilizing the CP NIP in the ED to decrease LOS.

\section{Validity and Reliability}

Validity confirms that the data results represent the proposed measure for the project (reduction of time) and reliability demonstrates consistency across time (gives stable and consistent results) (Sylvia \& Terhaar, 2018). To ensure high data accuracy reliability, the project manager and the data collection team set normalized collection and interpretation processes. Permission and final approval for data collection came from the Chief of Strategic Analytics, the medical facility Director, and the ED Medical Director. The project manager and a SAIL team statistician supervised the quantitative data collection process to safeguard project data analysis (VA, n.d.). The project manager was an active part of data collection, evaluation, and chart reviews with the statistician.

\section{Data Analysis}

A quantitative process using IBM SPSS and Microsoft Excel were applied throughout this project to collect, organize, and analyze the data to determine CP patient LOS. The data collection tool was a Microsoft Excel document and provided each data collection category for the project. Data collection included the date for the ED visit, registration time, time to triage, time NIP initiated, 12 lead EKG time, time seen by a provider, and discharge time

The data collection originated from the computerized patient record system (CPRS), a reliable and valid EHR source used by all VA Medical Centers (VA, n.d.). Pre-implementation data was collected using chart audits before starting the NIP process. All qualified CP cases were reviewed, and data collection of the NIP process was completed at 7 days, 14 days, 30 days, 45 days, and 60 days, post-NIP implementation. Chart audits aided in NIP compliance 
among the nursing staff, and constructive feedback was provided to strive for NIP compliance at $\geq 90 \%$ with all CP patients. Data categories were entered into the IBM SPSS system and checked for accuracy before final calculations were made with the primary data of LOS in the project.

A reliable VA medical center statistician assisted in the application of appropriate statistical tests for data analysis. Microsoft Excel spreadsheets with the collected data were shared with the statistician to complete the data analysis. The project manager utilized several methods to collaborate with the statistician, including face-to-face conversations, email, instant messaging, and phone calls. Analysis of the data was considered statistically significant, with pvalues $<0.05$ in the outcome data. Tests included an independent t-test for data analysis of ED LOS, times to EKG completion, and staff satisfaction measurement using the NIP during the project.

During the first week of the implementation of the project, the ED provider group changed. The outgoing group was very supportive and endorsed the use of NIP for CP patients. The new ED providers were not supportive and demonstrated high resistance levels toward the clinical staff trained to use the protocols. Seventeen nurses out of 35 nurses used the protocols during the project.

Length of stay was the primary dependent variable in the project. New ED providers that were not supportive of the NIP implementation adversely impacted LOS during the project. Additional COVID-19 restrictions contributed to LOS times during the project since all admissions and transfers required a completed COVID-19 screening before the final disposition from the ED. Table 3 reflects the LOS during pre- and post-implementation phases in minutes and was not statistically significant. Figure 5 provides a bar graph of the data results. 
Benefits of the project were found during data analysis involving EKG times. Table 4 displays the results in EKG time in both phases. Figure 6 provides a line graph showing improvements in the times during the project. The completion of EKG times dropped considerably. This change was considered statistically significant with a p value of $<0.05$.

The nurse educator and project manager completed education for staff until $90 \%$ compliance was achieved prior to the implementation. Staff satisfaction for using the NIP for CP patients was completed and demonstrated $90 \%$ of staff completed pre-implementation education and, subsequently, supported the NIP. The result was clinically significant and indispensable to achieving timely and high-quality patient care for $\mathrm{CP}$ patients in the ED.

\section{Formative Evaluation}

The formative evaluations were used during the implementation timeframe for project progress and to deliver constructive feedback for any improvements needed (Nelson \& Staggers, 2017). Weekly evaluations involving clinical staff were completed during shift change huddles to discuss concerns and to make recommendations. Obstacles or disorganization in the processes were noted using the PDSA cycles to identify opportunities to improve subsequent cycles for project success. Balancing measures were used to ensure appropriate ED staff education minimized negative impacts.

\section{Summative Evaluation}

At the end of the project, a summative evaluation was completed to calculate outcomes, influence the organization's project, and ensure the interventions met the stated goals (Nelson \& Staggers, 2017). Throughout the project, data collection provided levels of effectiveness of the NIP in decreasing LOS in the ED for CP patients in 8-weeks. A secondary benefit from the project included reduced times to EKG completion during the summative evaluation. 


\section{Protection of Human Rights and Privacy}

The project proposal was submitted for approval to the University EPRC and VA facility approval was obtained through an affiliate institutional review board (IRB), ensuring it did not include humans subject research. Final project review by the Veteran Affairs Research and Development committee also verified no human subject data involvement. Ethical considerations with ongoing monitoring safeguarded the data to ensure the protection of human rights and privacy.

All measures and outcomes were assessed using an accurate SPSS data collection method throughout the project. Data was stored in the electronic health record and secured by a two-step authentication process on the VA network assessable by the project manager and statistician. Patient identifiers were not used, and the collection tool only reflected numeric patient identifiers.

\section{Impact and Implications}

This evidence-based practice project's primary outcome was not entirely successful in decreasing LOS for CP patients with implementation of the NIP; however, secondary outcomes were seen in improved EKG completion times. There was a reduction in the LOS for CP patients despite the challenges and clinical significance with a reduction in LOS but marginal changes in the completion of diagnostic testing. The ED nurses had a higher level of autonomy and conveyed a sense of empowerment from the new protocol. The nursing staff was supportive and compliant in attempting to implement the NIP for the qualifying patients. The process measure reflecting a $90 \%$ compliance with completion of nursing education was met. Education for the NIP had positive effects among the triage nurses in recognizing the chest pain patient's clinical 
needs sooner. Successes in the project may help support further education and implement additional nurse-initiated protocols in the ED.

The evidence-based project's strengths included enhanced relationships among the interdisciplinary teams during the ED's implementation phase. The NIP included diagnostic lab studies, radiology orders, and nursing orders to have a 12-lead EKG within 10 minutes of the patient's arrival. While using this protocol, it covers the clinical staff legally for the care they initiate before a physician evaluation and resulted in a standardized clinical process for $\mathrm{CP}$ patients. Overall, the NIP change made a dynamic impact on the CP patients' lives with a clinically substantial reduction of EKG times to less than 10 minutes. No adverse financial effect was noted by implementing the $\mathrm{CP}$ protocol during the project, thereby being a cost-effective improvement.

The most significant barrier to this EBP project was resistance exhibited by physicians. The defiance of the physicians obstructed the ability of nurses to implement the protocol during the study. Only five of the ED physicians supported the nurses using the NIP for CP during the project. The original implementation phase had to be shortened to 8 weeks from the proposed 12week timeframe due to students' COVID-19 restrictions. As previously stated, the length of stay was not decreased during this project; nonetheless, a decrease in EKG completion times was statistically significant and had positive results confirming the potential for reducing LOS for CP patients in the future.

Limitations to success included the contract ED providers and COVID-19 restrictions. Despite these concerns, success including the decreased time to EKG completion. Improvements in education for ED providers, open communication among personnel, and integrating current 
evidence-based resources could assist with future success in the nurse-initiated protocol implementation in the ED.

\section{Plans for Dissemination}

Dissemination is crucial to EBP project success, with key stakeholder involvement in presenting and sharing findings (Fiset et al., 2017). Project accomplishment included a comprehensive review and evaluation of strengths, weaknesses, and opportunities for refining future use of nurse-initiated protocols in the ED. Comments and feedback originated from ED clinical staff, ED providers, the project mentor, course instructor, and academic peers. Initial project results and achievements were disseminated to the ED medical director and clinical staff during a virtual staff meeting.

A summary poster presentation will encompass sharing project outcomes at the facility level to Quality Management and Patient Safety, nursing management, and executive leadership within the organization. Key stakeholders and project team members will participate in the original presentations of project outcomes within the ED and facility. The plan for external dissemination will consist of a coordinated virtual poster presentation to ED departments within the regional Veterans Affairs system dependent on COVID-19 restrictions. The publication will be considered in the Journal of Emergency Nursing to communicate findings with equivalent nursing professional groups in emergency nursing. Journal submission provides an opportunity to disseminate information validating benefits of NIPs in the ED broadly and to corroborate that evidence-based practices can improve patient outcomes (Wolf, 2015). A full text submitted to the SOAR@USA institutional repository will be completed as a part of the DNP program requirements to enhance the discoverability of this EBP project. Furthermore, final submission to the Sigma Repository will be completed to distribute the project material worldwide. 


\section{Conclusion}

The project's goal included successfully developing and implementing a nurse-initiated protocol for patient populations with $\mathrm{CP}$ complaints in the ED to decrease LOS and improve flow. A well-organized and evidence-based chest pain protocol in the ED can decrease LOS and avoid adverse outcomes associated with delays in the treatment of ACS or AMI diagnosis imperative for healthier patient outcomes (Bunch et al., 2016). Decreased LOS is a literaturesupported metric for efficiency and vital in ED flow improvement (Douma et al., 2016). This project did not demonstrate statistically significant data decreasing LOS yet did have success showing a reduction in EKG times and considered a clinically successful component of the EBP project.

In summary, results showed nurse-driven protocols for $\mathrm{CP}$ patient populations can positively impact LOS in the ED and, residually, improve patient satisfaction (Hwang et al., 2016). Project outcomes were communicated to the immediate department and organization to gain support for the intervention's sustainability. The project manager will consider opportunities for publication to the Journal of Emergency Nursing after organizational approval. 


\section{References}

Andruchow, J. E., Kavsak, P. A., \& McRae, A. D. (2018). Contemporary emergency department management of patients with chest pain: A concise review and guide for the highsensitivity troponin era. Canadian Journal of Cardiology, 34(2), 98-108. https://doi.org/10.1016/j.cjca.2017.11.012

Baugh, C. W., Greenberg, J. O., Mahler, S. A., Kosowsky, J. M., Schuur, J. D., Parmar, S., Ciociolo, G., Carr, C., Ghazinouri, R., \& Scirica, B. (2016). Implementation of a risk stratification and management pathway for acute chest pain in the emergency department. Critical Pathways in Cardiology, 15(4), 131-137. http://dx.doi.org/10.1097/HPC.0000000000000095

Bunch, A., Leasure, A., Carithers, C., Burnette Jr, R. E., \& Berryman Sr, M. S. (2016). Implementation of a rapid chest pain protocol in the emergency department: A quality improvement project. Journal of the American Association of Nurse Practitioners, 28(2), 75-83. https://doi.org/10.1002/2327-6924.12260

Burgess, L., \& Kynoch, K. (2017). Effectiveness of nurse-initiated interventions on patient outcomes in the emergency department: A systematic review protocol. JBI Database of Systematic Reviews and Implementation Reports, 15, 873-881. https://doi.org/10.11124/JBISRIR-2016-003042

Burgess, L., Kynoch, K., \& Hines, S. (2018). Implementing best practice into the emergency department triage process. International Journal of Evidence-Based Healthcare, 16(16), 1-9. https://doi.org/10.1097/XEB.0000000000000144 
Chang, A., Lin, A., Fu, R., McConnell, K., \& Sun, B. (2017). Associations of emergency department length of stay with publicly reported quality-of-care measures. Academic Emergency Medicine, 24(2), 246-250. https://doi.org/10.1111/acem.13102

Choy, L. T. (2014). The strengths and weaknesses of research methodology: Comparison and complimentary between qualitative and quantitative approaches. IOSR Journal of Humanities and Social Science, 19(4), 99-104. https://doi.org/10.9790/0837-194399104

Douma, M. J., Drake, C. A., O'Dochartaigh, D., \& Smith, K. E. (2016). A pragmatic randomized evaluation of a nurse-initiated protocol to improve timeliness of care in an urban emergency department. Annals of Emergency Medicine, 68(5), 546-552. https://doi.org/10.1016/j.annemergmed.2016.06.019

Elder, E., Johnston, A. N., \& Crilly, J. (2015). Review article: Systematic review of three key strategies designed to improve patient flow through the emergency department. Emergency Medicine Australisia, 27, 394-404. https://doi.org/10.1111/1742-6723.12446 Emergency Nurse Association. (2015). Use of protocols in the emergency setting. https://www.ena.org/docs/default-source/resource-library/practice-resources/positionstatements/useofprotocolsined.pdf?sfvrsn=43f282ab_6

Fay, L., Carll-White, A., \& Real, K. (2018). Emergency nurses’ perceptions of efficiency and design: Examining ED structure, process, and outcomes. Journal of Emergency Nursing, 44(3), 274-279. https://doi.org/10.1016/j.jen.2017.09.001

Fiset, V. J., Graham, I. D., \& Davies, B. L. (2017). Evidence-based practice in clinical nursing education: A scoping review. Journal of Nursing Education, 56(9), 534-541. https://doi.org/10.3928/01484834-20170817-04 
Higginson, I., Kehoe, A., Whyatt, J., \& Smith, J. E. (2017). The 4-hour standard is a meaningful quality indicator: correlation of performance with emergency department crowding. European Journal of Emergency Medicine, 24(1), 25-28. https: dx.doi.org/10.1097/MEJ.0000000000000417

Hussain, S. T., Lei, S., Akram, T., Haider, M. J., Hussain, S. H., \& Ali, M. (2018). Kurt Lewin's change model: A critical review of the role of leadership and employee involvement in organizational change. Journal of Innovation and Knowledge, 3(3), 123-127. https://doi.org/10.1016/j.jik.2016.07.002

Hwang, C. W., Payton, T., Weeks, E., \& Plourde, M. (2016, May 31). Implementing triage standing orders in the emergency department leads to reduced physician-to-disposition times. Advances in Emergency Medicine, 2016, 1-6. https://doi.org/10.1155/2016/7213625

Institute for Healthcare Improvement. (2020). Science of improvement: Establishing measures. http://www.ihi.org/resources/Pages/HowtoImprove/ScienceofImprovementEstablishingM $\underline{\text { easures.aspx }}$

Kankaanpaa, M., Raitakari, M., Muukkonen, L., Gustafsson, S., Heitto, M., Palomaki, A., Suojanen, K., \& Harjola, V.-P. (2016). Use of point-of-care testing and early assessment model reduces length of stay for ambulatory patients in an emergency department. Scandivavian Journal of Trauma, Resuscitation and Emergency Medicine, 24(125), 1-7. https://doi.org/10.1186/s13049-016-0319-z

Knudsen, S., Laursen, H., Johnsen, S., Bartels, P., Ehlers, L., \& Mainz, J. (2019). Can quality improvement improve the quality of care? A systematic review of reported effects and 
methodological rigor in plan-do-study-act projects. BMC Health Services Research, 19, 683. https://doi.org/10.1186/s12913-019-4482-6

Kocher, K. E. (2017). Achieving the holy grail of emergency department evaluation for chest pain. Circulation: Cardiovascular Quality and Outcomes, 10(10), e004026. https://doi.org/10.1161/CIRCOUTCOMES.117.004026

Lee, W. W., Filiatrault, L., Abu-Laban, R. B., Rashidi, A., Yau, L., \& Liu, N. (2016). Effect of triage nurse-initiated radiography using the ottawa ankle rules on emergency department length of stay at a tertiary centre. Canadian Journal of Emergency Medicine, 18(2), 9097. https://doi.org/10.1017.cem.2015.67

Lewin, K. (1947). Frontiers in group dynamics: Concept, method and reality in social science: Social equilibria and social change. Human Relations, 1(1), 5-41. https://doi.org/10.1177/001872674700100103

Long, B., Oliver, J., Streitz, M., \& Koyfman, A. (2017). An end-user's guide to the HEART score and pathway. American Journal of Emergency Medicine, 35(9), 1350-1355. https://doi.org/10.1016/j.ajem.2017.03.047

Mahler, S., Lenoir, K., Wells, B., Burke, G., Duncan, P., Case, L. D., Herrington, D., DiazGarelli, J., Futrell, W., Hiestand, B., \& Miller, C. (2018). Safely indentifying emergency department patients with acute chest pain for early discharge. Circulation, 138(22), 2456-2468. https://doi.org/10.1161/CIRCULATIONAHA.118.036528

Miake-Lye, I., O'Neil, S., Childers, C., Gibbons, M., Mak, S., Shannon, R., Beroes, J. M., \& Shekelle, P. G. (2017). Effectiveness of interventions to improve emergency department efficiency: An evidence map (VA ESP Project \#05-226). https://www.ncbi.nlm.nih.gov/books/NBK513772/ 
Morley, C., Unwin, M., Peterson, G. M., Stankovich, J., \& Kinsman, L. (2018, August 30). Emergency department crowding: A systematic review of causes, consequences and solutions. PLoS ONE, 13(8), 1-42. https://doi.org/10.1371/journal.pone.0203316

Nelson, R., \& Staggers, N. (2017). Health Informatics, An Interprofessional Approach (2nd ed.). Elsevier.

Pierce, B. A., \& Gromley, D. (2016, April 26). Are split flow and provider in triage models in the emergency department effective in reducing discharge length of stay? Journal of Emergency Nursing, 42(6), 487-491. https://doi.org/10.1016.j.jen.2016.01.005

Reinhardt, M. R. (2017, July 1). A systematic approach to evaluation of performance deficiencies in ED triage. Journal of Emergency Nursing, 43(4), 429-432. https://doi.org/10.1016/j.jen.2017.01.003

Riley, R., Miller, C., Russell, G., Harper, E., Hiestand, B., Hoekstra, J., Lefebvre, C., Nicks, B., Cline, D., Askew, K., \& Mahler, S. (2017). Cost analysis of the history, ECG, age, risk factors, and initial Troponin (HEART) Pathway randomized control trial. The American Journal of Emergency Medicine, 35(1), 77-81. https://doi.org/10.1016/j.ajem.2016.10.005

Ro, Y. S., Shin, S. D., Song, K. J., Cha, W. C., \& Cho, J. S. (2015). Triage-based resource allocation and clinical treatment protocol on outcome and length of stay in the emergency department. Emergency Medicine Australasia, 27, 328-335. https://doi.org/10.1111/1742-6723.12426

Rosenberg, K. (2016, November 1). Nures-initiated protocols can reduce ED wait times. American Journal of Nursing, 116(11), 62. https://doi.org/10.1097/01.NAJ.0000505594.70579.e2 
Shahmoradi, L., Darrudi, A., Arji, G., \& Nejad, A. F. (2017). Electronic health record implementation: A SWOT analysis. Acta Medica Iranica, 55(10), 642-649. https://pdfs.semanticscholar.org/9d3c/d179cdb8d07c61947afa60d8073c0c8f5c4d.pdf

Stauber, M. A. (2013). Advanced nursing interventions and length of stay in the emergency department. Journal of Emergency Nursing, 39(3), 221-225. https://doi.org/10.1016/j.jen.2012.02.015

Sylvia, M. L., \& Terhaar, M. F. (2018). Clinical analytics and data management for the DNP (2nd ed.). Springer Publishing Company, LLC.

Than, M. P., \& Pickering, J. W. (2018). ICare-ACS (Improving Care Processes for Patients with suspected Acute Coronary Syndrome): A study of cross-system implementation of a national clinical pathway. Circulation, 137(4), 354-363. https://doi.org/10.1161/CIRCULATIONAHA.117.031984

U.S. Department of Veterans Affairs. (n.d.). Strategic analytics for improvement and learning (SAIL). https://sail.vssc.med.va.gov/

U.S. Department of Veterans Affairs. (2019). Charlie Norwood VA Medical Center. https://www.augusta.va.gov/about/

Warner, L. S., Pines, J. M., Gibson, J., \& Schuur, J. D. (2015, December 1). The most crowded US hospital emergency departments did not adopt effective interventions to improve flow. Health Affairs; Chevy Chase, 34(12), 2151-2159A. https://doi.org/10.1377/hlthaff.2015.0603

Wolf, L. (2015). Getting the word out: Dissemination of research results. Journal of Emergency Nursing, 41(5), 451-452. http://dx.doi.org/10.1016/j.jen.2015.06.001 
Wright, D. (2005). Competency assessment in healthcare (3rd ed.). Creative Health Care Management.

Yiadom, M., Baugh, C., McWade, C., Liu, X., Song, K., Patterson, B., Jenkins, C., Tanski, M., Mills, A., Salazar, G., Wang, T., Dittus, R., Liu, D., \& Storrow, A. (2017). Performance of emergency department screening criteria for an early ECG to identify ST-segment elevation myocardial infarction. Journal of the American Heart Association, 6(3), e003528. https://doi.org/10.1161/JAHA.116.003528 


\section{Table 1}

Projected Budget

\begin{tabular}{llll}
\hline Item & Description & Total & Comments \\
\hline Salaries for ED RNs & Expense for & $\$ 1,260.00$ & Total projected expense for a \\
(36 total) & education for NIP & & 1-hour training session per RN. \\
& & & Average hourly rate $=\$ 35.00$.
\end{tabular}

\section{Revenue}

\begin{tabular}{llll}
\hline Decreased LOS & $\begin{array}{l}\text { Amount saved } \\
\text { with one-hour } \\
\text { LOS in ED }\end{array}$ & $\$ 100.00 /$ patient & $\begin{array}{l}\text { Average cost/hour for CP } \\
\text { evaluation in the ED }= \\
\$ 1,000.00 .\end{array}$ \\
\hline $\begin{array}{l}\text { Number of CP } \\
\text { patients/month }\end{array}$ & $\begin{array}{l}\text { Average 18\% } \\
\text { total patients seen } \\
\text { for CP }\end{array}$ & $\begin{array}{l}\$ 8000.00 / \text { month } \\
\text { savings }\end{array}$ & $\begin{array}{l}\text { Monthly average }=80 \text { patient } \\
\text { evaluated for CP }\end{array}$ \\
\hline
\end{tabular}

\begin{tabular}{llll}
\hline Cost-Benefit & Net benefit from & $1^{\text {st }}$ year $=$ & Estimated saving in first year, \\
& NIP for CP & $\$ 90,120.00$ & $\begin{array}{l}\text { post-implementation of CP } \\
\text { NIP in the ED. }\end{array}$
\end{tabular}




\section{Table 2}

Measures, Goals, and Statistical analysis

\begin{tabular}{|c|c|c|c|c|}
\hline Measure & Category & Definition & Goal & Statistical Test/Data Type \\
\hline ED LOS & Outcome & $\begin{array}{l}\text { Length of time in the ED from time of registration to final disposition } \\
\text { out of the ED: can be discharged, admission or transfer. }\end{array}$ & $\leq 240$ minutes & $\begin{array}{l}\text { Continuous data/ unpaired t- } \\
\text { test }\end{array}$ \\
\hline Time to EKG & Outcome & Length of time from triage until completion of 12-lead EKG. & $\begin{array}{l}\geq 90 \% \text { patients } \\
\text { with EKG } \\
\text { completion } \leq 10 \\
\text { minutes }\end{array}$ & $\begin{array}{l}\text { Ratio data/measures of } \\
\text { frequency }\end{array}$ \\
\hline $\begin{array}{l}\text { Percent of staff to } \\
\text { complete NIP } \\
\text { education }\end{array}$ & Process & $\begin{array}{l}\text { Percentage of clinical staff to successfully complete NIP education. } \\
\text { Numerator is number of staff completing education \& denominator is } \\
\text { total number of staff. }\end{array}$ & & Categorical data / $\mathrm{X}^{2}$ \\
\hline $\begin{array}{l}\text { Percentage of staff } \\
\text { satisfied with NIP use }\end{array}$ & Balance & $\begin{array}{l}\text { Percentage of staff reporting satisfaction using NIP for CP patients. } \\
\text { Numerator is number of staff to report satisfaction \& denominator is } \\
\text { total number of staff. }\end{array}$ & & Categorical data / $\mathrm{X}^{2}$ \\
\hline Cost of Training & Financial & Total number of clinical staff multiplied by hourly rate $\mathrm{x} 1$ hour. & $\begin{array}{l}\$ 1,260.00 \text { with } \\
\text { average hourly rate } \\
\text { of } \$ 35.00\end{array}$ & \\
\hline
\end{tabular}




\section{Table 3}

Length of Stay for Chest Pain Patients

\begin{tabular}{llllll}
\hline Variable & $N$ & Mean & Median & SD & $P$ \\
\hline Pre-Implementation & 29 & 331.36 & 326.37 & 144.84 & 0.372 \\
Post-Implementation & 29 & 302.54 & 294.61 & 99.34 & \\
\hline
\end{tabular}

Note: Time is noted in Minutes. 


\section{Table 4}

EKG Times for Chest Pain Patients

\begin{tabular}{lllllll}
\hline Variable & $N$ & Mean & $S D$ & $D f$ & $t$ & $p$ \\
\hline Pre-Implementation & 29 & 39.4 & 29.4 & 29.6 & 1.703 & 0.046 \\
Post-Implementation & 29 & 9.3 & 25.5 & & & \\
\hline
\end{tabular}

Note: Time is noted in Minutes. 


\section{Figure 1}

Article selection criteria

\section{Inclusion criteria applied}

\section{Exclusion criteria applied}

Unpublished article or report

Publication with no MeSH indexing

Publications outside date range

Articles without author or unclear

Abstracts or full-text unavailable

Includes nurse-initiated orders / protocols 


\section{Figure 2}

\section{PRISMA Summary}
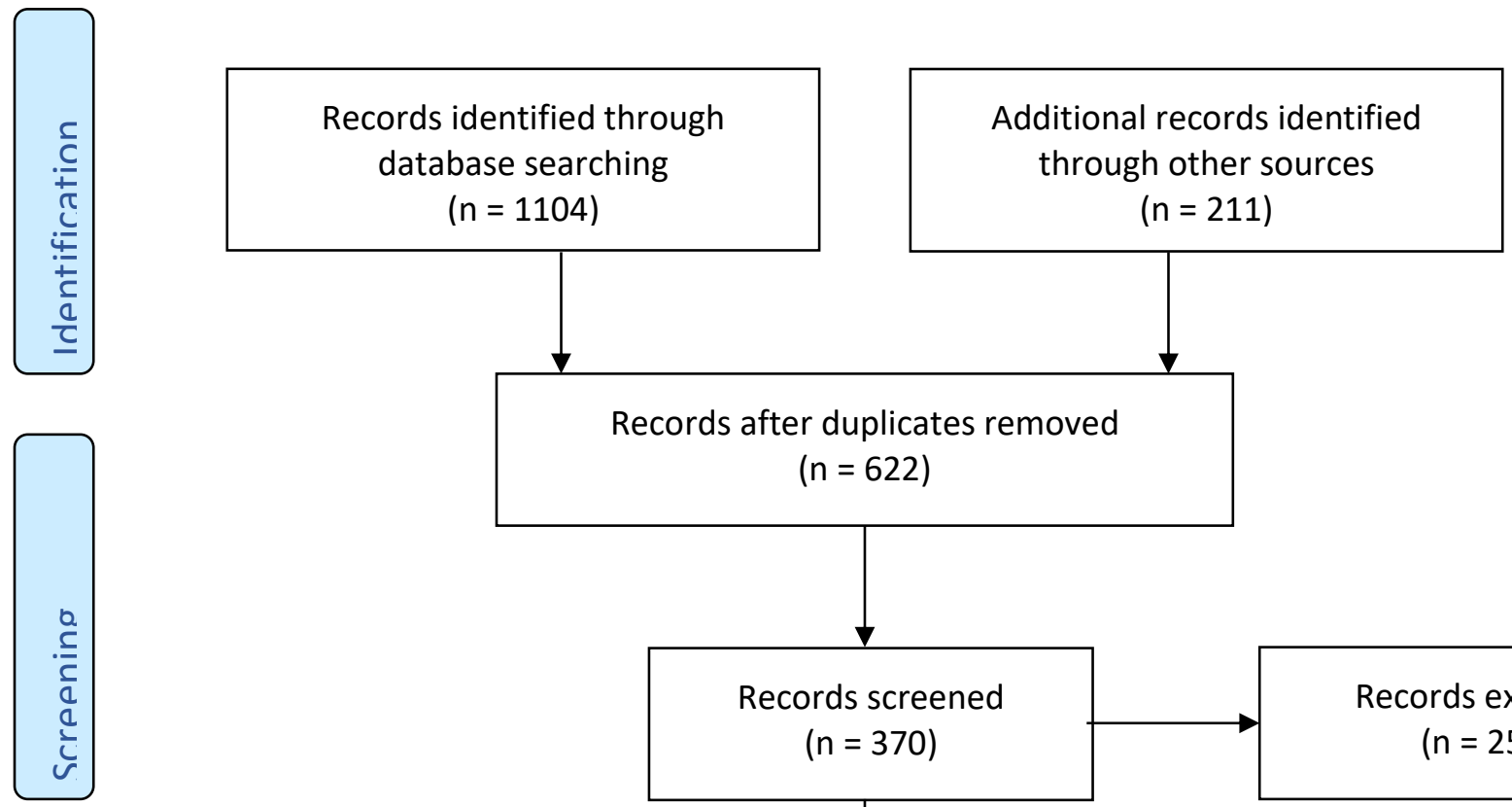

Records after duplicates removed
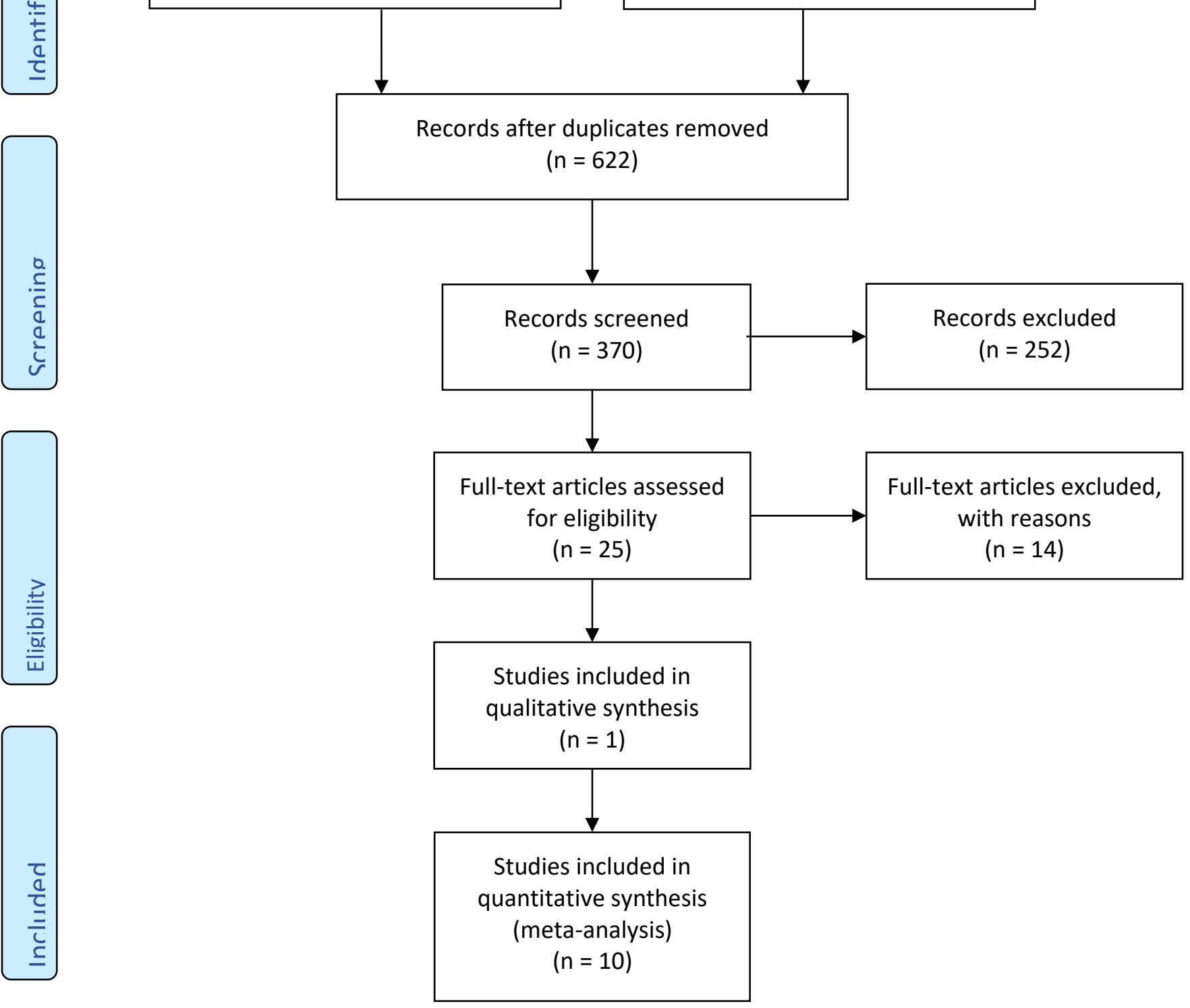

From: Moher D, Liberati A, Tetzlaff J, Altman DG, The PRISMA Group (2009). Preferred Reporting Items for Systematic Reviews and Meta-Analyses: The PRISMA Statement. PLoS Med 6(7): e1000097. doi:10.1371/journal.pmed1000097 


\section{Figure 3}

\section{SWOT Analysis}

\section{STRENGTHS}

- Leadership support

- Positive Teamwork in the Emergency Department

- Clinical judgment skills

- Improved patient satisfaction

\section{OPPORTUNITIES}

- ED EBP/CNL growth

- Activating protocols

- Empowering nursing staff

- Collaborate between professions; improved relationships

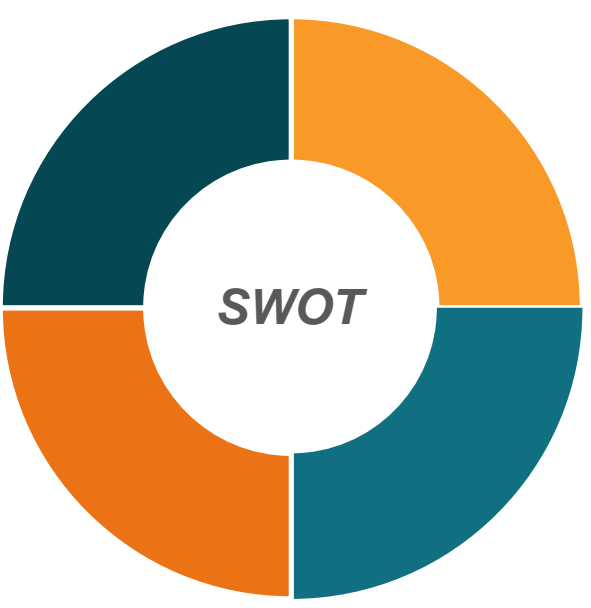

\section{THREATS}

- Variance in clinical assessments

- Resistance to change

- Rejection by Providers

- Staff bias and work arounds 


\section{Figure 4}

Fishbone RCA Tool

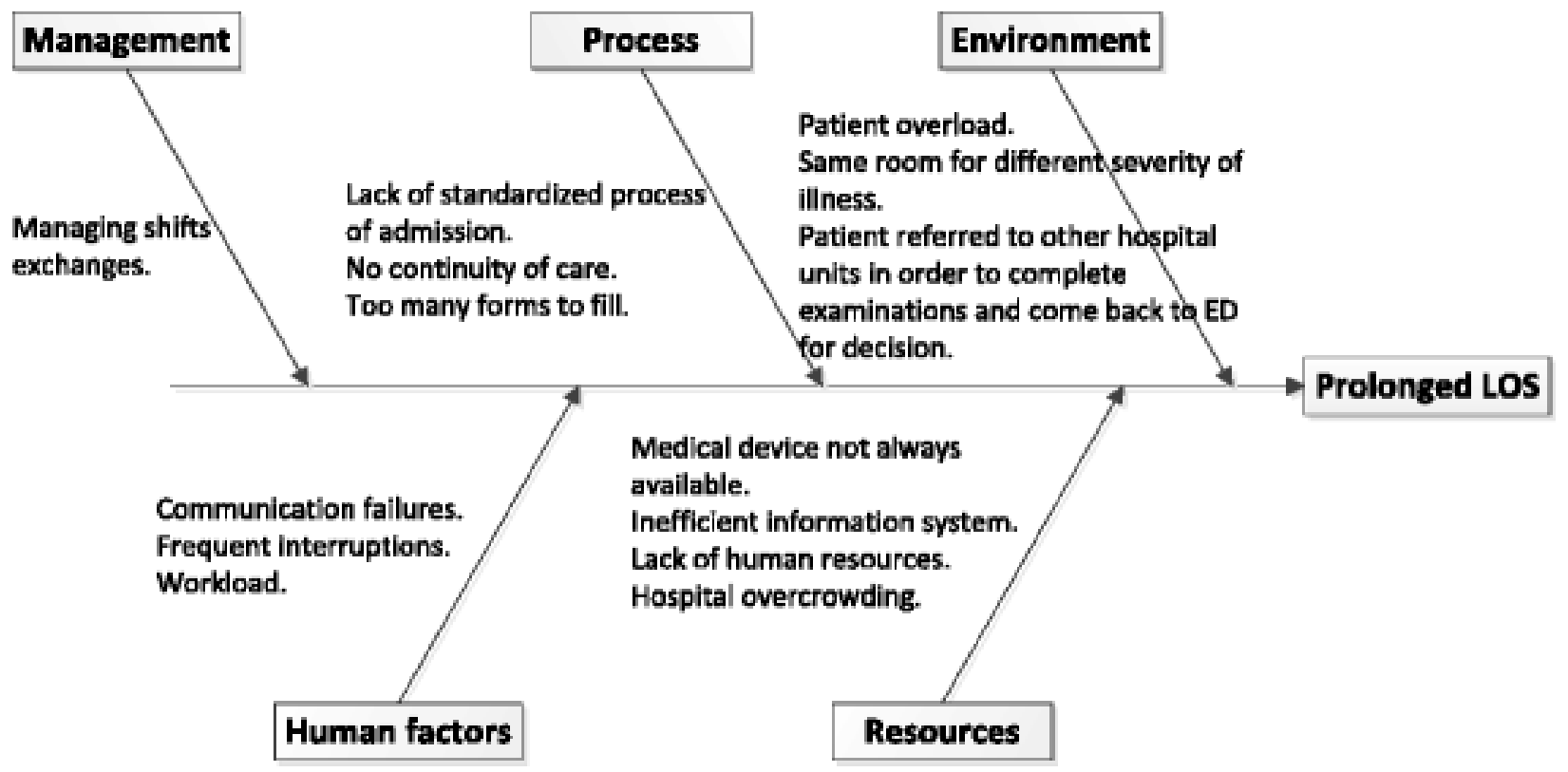


Figure 5

Length of Stay Pre \& Post Implementation

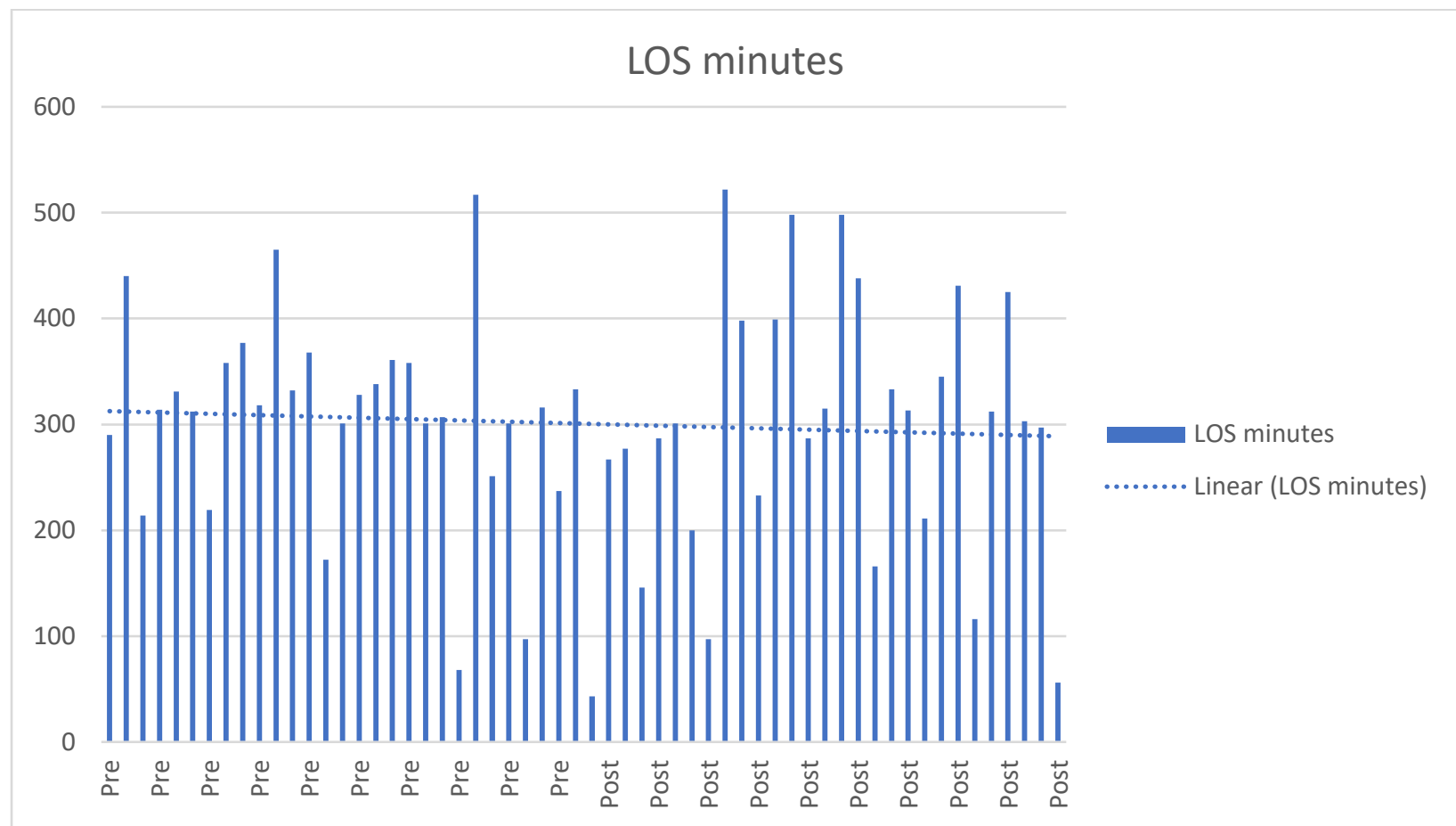


Figure 6

Time for EKG Completion

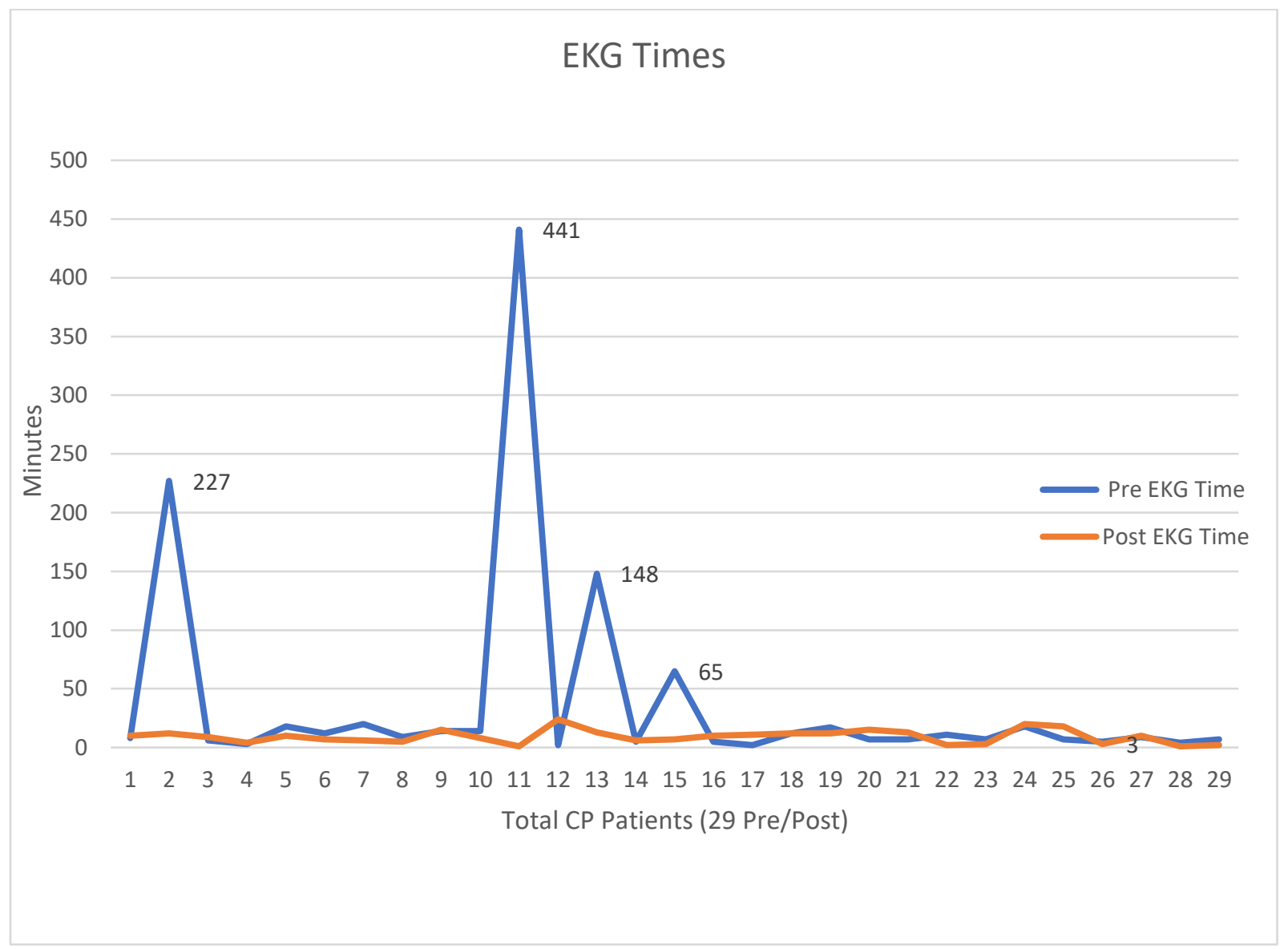


Appendix A

Summary of Primary Research Evidence

\begin{tabular}{|c|c|c|c|c|c|c|c|}
\hline Citation & $\begin{array}{l}\text { Design, } \\
\text { Method }\end{array}$ & $\begin{array}{l}\text { Sample } \\
\text { size, } \\
\text { Setting }\end{array}$ & $\begin{array}{l}\text { Variables } \\
\& \\
\text { Definitions }\end{array}$ & $\begin{array}{l}\text { Data } \\
\text { Analysis }\end{array}$ & $\begin{array}{l}\text { Conceptu } \\
\text { al } \\
\text { Framewo } \\
\text { rk }\end{array}$ & $\begin{array}{l}\text { Key } \\
\text { Findings }\end{array}$ & $\begin{array}{l}\text { Quality } \\
\text { \& Level } \\
\text { of } \\
\text { Evidence } \\
\text { (John } \\
\text { Hopkins) }\end{array}$ \\
\hline $\begin{array}{l}\text { Douma, M. J., } \\
\text { Drake, C. A., } \\
\text { O'Dochartaigh, D., } \\
\text { \& Smith, K. E. } \\
\text { (2016). A pragmatic } \\
\text { randomized } \\
\text { evaluation of a } \\
\text { nurse-initiated } \\
\text { protocol to improve } \\
\text { timeliness of care in } \\
\text { an urban emergency } \\
\text { department. Annals } \\
\text { of Emergency } \\
\text { Medicine, 68(5), } \\
\text { 546-552. }\end{array}$ & $\begin{array}{l}\text { Computer- } \\
\text { randomized, } \\
\text { pragmatic, } \\
\text { controlled } \\
\text { evaluation; } \\
\text { blinded } \\
\text { study } \\
\text { analysis. }\end{array}$ & $\begin{array}{l}143 \\
\text { patients } \\
\text { from a } \\
\text { medium- } \\
\text { sized, } \\
\text { western } \\
\text { Canadian } \\
\text { emergenc } \\
\text { y } \\
\text { departme } \\
\text { nt. } \\
76 \\
\text { protocol } \\
\text { group } \\
\text { with 67 in } \\
\text { controlled } \\
\text { group; } \\
\text { patient } \\
\text { EMR. }\end{array}$ & $\begin{array}{l}\text { Comparison } \\
\text { of } \\
\text { implemented } \\
\text { nursing } \\
\text { protocols to } \\
\text { no protocol } \\
\text { use; } \\
\text { obtaining } \\
\text { standardized } \\
\text { care in the } \\
\text { ED. }\end{array}$ & $\begin{array}{l}\text { Blind } \\
\text { fashion } \\
\text { statistical } \\
\text { analysis; } \\
\text { median } \\
\text { outcome } \\
\text { times, with } \\
\text { interquartil } \\
\text { e ranges, } \\
\text { were } \\
\text { calculated. } \\
\text { Bonett and } \\
\text { Price tool } \\
\text { was used. } \\
\text { Intention- } \\
\text { to-treat } \\
\text { analysis } \\
\text { also } \\
\text { completed. }\end{array}$ & None & $\begin{array}{l}\text { The use of } \\
\text { protocols to } \\
\text { initiate } \\
\text { diagnostics } \\
\text { can } \\
\text { decrease } \\
\text { LOS in } \\
\text { specific, } \\
\text { carefully } \\
\text { selected } \\
\text { patient } \\
\text { groups. }\end{array}$ & $\begin{array}{l}\text { Level I, A } \\
\text { Credible } \\
\text { blind } \\
\text { method \& } \\
\text { analysis } \\
\text { tools. }\end{array}$ \\
\hline $\begin{array}{l}\text { Hwang, C. W., \& } \\
\text { Payton, T. (2016). } \\
\text { Implementing } \\
\text { Triage standing } \\
\text { orders in the } \\
\text { emergency } \\
\text { department leads to } \\
\text { reduced physician- } \\
\text { to-disposition times. } \\
\text { Advances in } \\
\text { Emergency } \\
\text { Medicine, 2016, 1- } \\
\text { 6. }\end{array}$ & $\begin{array}{l}\text { Retrospectiv } \\
\text { e cohort } \\
\text { study with } \\
\text { data } \\
\text { collection } \\
\text { from patient } \\
\text { EMR. }\end{array}$ & $\begin{array}{l}\text { Universit } \\
\text { y of } \\
\text { Florida, } \\
\text { College of } \\
\text { Medicine: } \\
149 \text { SO } \\
\text { cohort } \\
\text { group; } \\
152 \text { non- } \\
\text { SO cohort } \\
\text { group. }\end{array}$ & $\begin{array}{l}\text { SO } \\
\text { implementat } \\
\text { ion for } \\
\text { patients } \\
\text { presenting } \\
\text { with chest } \\
\text { pain (CP) } \\
\text { compared to } \\
\text { patients not } \\
\text { having SO } \\
\text { use. }\end{array}$ & $\begin{array}{l}\text { The SO } \\
\text { cohort was } \\
\text { analyzed; } \\
\text { SO \& } \\
\text { complete } \\
\text { lab results } \\
\text { vs. SO and } \\
\text { partial lab } \\
\text { results } \\
\text { prior to } \\
\text { Provider } \\
\text { assessment. }\end{array}$ & None & $\begin{array}{l}\text { SO groups } \\
\text { had } \\
\text { reduction in } \\
\text { disposition } \\
\text { times from } \\
154 \text { to } 128 \\
\text { minutes: } 26- \\
\text { minute } \\
\text { decrease = } \\
16.9 \% \\
\mathrm{p}=0.04\end{array}$ & $\begin{array}{l}\text { Level II, A } \\
\text { Credible } \\
\text { method } \\
\text { with large } \\
\text { sample } \\
\text { size. }\end{array}$ \\
\hline $\begin{array}{l}\text { Bunch, A. M., } \\
\text { Leasure, A. R., } \\
\text { Carithers, C., } \\
\text { Burnette Jr, R. E., \& } \\
\text { Berryman Sr, M. S. } \\
\text { (2016). } \\
\text { Implementation of a } \\
\text { rapid chest pain } \\
\text { protocol in the } \\
\text { emergency } \\
\text { department: A } \\
\text { quality } \\
\text { improvement } \\
\text { project. Journal of } \\
\text { the American } \\
\text { Association of } \\
\text { Nurse }\end{array}$ & $\begin{array}{l}\text { Prospective } \\
\text { comparative } \\
\text { study of } \\
\text { patients in } \\
\text { the ED with } \\
\text { CP. }\end{array}$ & $\begin{array}{l}\text { 15-bed } \\
\text { single } \\
\text { facility } \\
\text { ED of a } \\
\text { metropolit } \\
\text { an area. } \\
64 \\
\text { patients in } \\
\text { standard } \\
\text { and } \\
\text { accelerate } \\
\text { d groups. }\end{array}$ & $\begin{array}{l}\text { Comparing } \\
\text { the existing } \\
\text { chest pain } \\
\text { protocol of } \\
120 \text { minutes } \\
\text { (standard } \\
\text { care) with a } \\
\text { rapid } \\
\text { evaluation } \\
\text { protocol of } \\
90 \text { minutes. }\end{array}$ & $\begin{array}{l}\text { Mean \& } \\
\text { standard } \\
\text { deviations } \\
\text { between } \\
\text { groups with } \\
\text { independen } \\
\mathrm{t} t \text {-tests. } \mathrm{p}= \\
0.05 . \\
\text { standard } \\
\text { ( } \mathrm{n}=64) \\
\text { accelerated } \\
\text { (n=64). } \\
\text { SPSS } \\
\text { analysis. } \\
\text { Chi Square } \\
\text { used for } \\
\text { differences } \\
\text { in groups. } \\
\end{array}$ & $\begin{array}{l}\text { Promoting } \\
\text { Action on } \\
\text { Research } \\
\text { Implement } \\
\text { ation in } \\
\text { Health } \\
\text { Services } \\
\text { (PARIHS) } \\
\text { framework }\end{array}$ & $\begin{array}{l}\text { Use of } \\
\text { accelerated } \\
\text { protocols } \\
\text { reduced } \\
\text { LOS by } 73 \\
\text { minutes } \\
\text { without } \\
\text { increase in } \\
\text { adverse } \\
\text { events and } \\
\text { provided } \\
\text { ED } \\
\text { clinicians } \\
\text { with } \\
\text { accurate } \\
\text { AMI } \\
\text { evaluation. }\end{array}$ & $\begin{array}{l}\text { Level II, A } \\
\text { Clinical } \\
\text { practice } \\
\text { protocols } \\
\text { with equal } \\
\text { group } \\
\text { comparison } \\
\text { s. }\end{array}$ \\
\hline
\end{tabular}




\begin{tabular}{|c|c|c|c|c|c|c|c|}
\hline $\begin{array}{l}\text { Practitioners, } 28(2), \\
75-83 \text {. }\end{array}$ & & & & & & & \\
\hline $\begin{array}{l}\text { Baugh, C. W., } \\
\text { Greenberg, J. O., } \\
\text { Mahler, S. A., } \\
\text { Kosowsky, J. M., } \\
\text { Schuur, J. D., } \\
\text { Parmar, S., ... \& } \\
\text { Scirica, B. M. } \\
\text { (2016). } \\
\text { Implementation of a } \\
\text { risk stratification } \\
\text { and management } \\
\text { pathway for acute } \\
\text { chest pain in the } \\
\text { emergency } \\
\text { department. Critical } \\
\text { pathways in } \\
\text { cardiology, 15(4), } \\
\text { 131. }\end{array}$ & $\begin{array}{l}\text { Single } \\
\text { center, } \\
\text { prospective } \\
\text { cohort of } \\
\text { patient } \\
\text { complaints } \\
\text { of ACS. } \\
\text { Patient } \\
\text { EMR. }\end{array}$ & $\begin{array}{l}\text { Urban, } \\
\text { tertiary- } \\
\text { care } \\
\text { hospital } \\
\text { with } \\
60,050 \\
\text { ED visits; } \\
239 \\
\text { patients } \\
\text { studied. }\end{array}$ & $\begin{array}{l}\text { SCAMP for } \\
\text { CP on } \\
\text { HEART } \\
\text { score. } \\
\text { Low }(\mathrm{n}=54) \text {, } \\
\text { intermediate } \\
(\mathrm{n}-40) \text {, and } \\
\text { high }(\mathrm{n}=3) \\
\text { risk tiers. }\end{array}$ & $\begin{array}{l}\text { Chi square } \\
\text { \& Fisher } \\
\text { exact tests } \\
\text { used. } \\
\text { Wilcoxon } \\
\text { rank sum } \\
\text { tests for } \\
\text { mean LOS. }\end{array}$ & None & 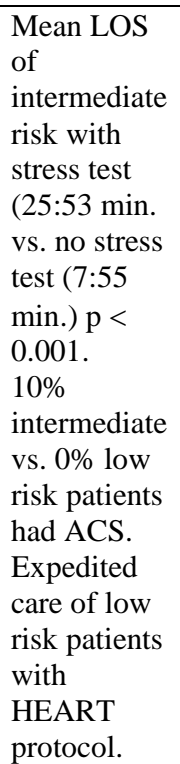 & Level I, A \\
\hline $\begin{array}{l}\text { Crilly, J., } \\
\text { Greenslade, J. H., } \\
\text { Berndt, S., } \\
\text { Hawkins, T., \& } \\
\text { Cullen, L. (2020). } \\
\text { Facilitators and } \\
\text { barriers for } \\
\text { emergency } \\
\text { department } \\
\text { clinicians using a } \\
\text { rapid chest pain } \\
\text { assessment } \\
\text { protocol: qualitative } \\
\text { interview } \\
\text { research. BMC } \\
\text { Health Services } \\
\text { Research, 20(1), } 74 .\end{array}$ & $\begin{array}{l}\text { Qualitative, } \\
\text { retrospective } \\
\text { process } \\
\text { study; } \\
\text { followed } \\
\text { SRQR } \\
\text { guidelines. }\end{array}$ & $\begin{array}{l}\text { Nine } \\
\text { participan } \\
\text { ts } \\
\text { representi } \\
\text { ng } \\
\text { medical \& } \\
\text { nursing } \\
\text { staff } \\
\text { working } \\
\text { in a single } \\
\text { facility. } \\
\text { Using } \\
\text { IMPACT } \\
\text { protocol } \\
\text { for CP } \\
\text { patients. }\end{array}$ & $\begin{array}{l}\begin{array}{l}\text { Medical } \\
(\mathrm{n}=4)\end{array} \\
\text { Nursing } \\
(\mathrm{n}=5) \\
3 \text { males; } \\
\text { average } \\
\text { years of } \\
\text { experience } \\
17(\mathrm{SD}: 9.2) \\
\text { with } 12.6 \\
\text { years (SD: } \\
\text { 6.6) working } \\
\text { ED. }\end{array}$ & $\begin{array}{l}\text { Content } \\
\text { analysis } \\
\text { between } 2 \\
\text { researchers } \\
\text { to identify } \\
\text { theoretical } \\
\text { domains } \\
\text { that } \\
\text { facilitated } \\
\text { or hindered } \\
\text { protocol } \\
\text { use. }\end{array}$ & $\begin{array}{l}\text { Theoretical } \\
\text { Domains } \\
\text { Framework }\end{array}$ & $\begin{array}{l}\text { Social/profe } \\
\text { ssional role } \\
\text { and identity, } \\
\text { environment } \\
\text { al context } \\
\text { and } \\
\text { resources } \\
\text { with social } \\
\text { influences } \\
\text { were most } \\
\text { often } \\
\text { reported; } \\
\text { Sources for } \\
\text { protocol use } \\
\text { were leaders } \\
\text { \& } \\
\text { influences } \\
\text { from trusted } \\
\text { peers. }\end{array}$ & $\begin{array}{l}\text { Level III, B } \\
\text { Only single } \\
\text { facility } \\
\text { study with } \\
\text { small study } \\
\text { group. }\end{array}$ \\
\hline $\begin{array}{l}\text { Mahler, S. A., } \\
\text { Lenoir, K. M., } \\
\text { Wells, B. J., Burke, } \\
\text { G. L., Duncan, P. } \\
\text { W., Case, L. D., ... } \\
\text { \& Miller, C. D. } \\
\text { (2018). Safely } \\
\text { identifying } \\
\text { emergency } \\
\text { department patients } \\
\text { with acute chest } \\
\text { pain for early } \\
\text { discharge: HEART } \\
\text { pathway accelerated } \\
\text { diagnostic } \\
\text { protocol. Circulatio } \\
n, 138(22), 2456- \\
2468 .\end{array}$ & $\begin{array}{l}\text { Prospective } \\
\text { pre-post } \\
\text { study using } \\
\text { EMR, } \\
\text { insurance } \\
\text { claims, \& } \\
\text { death index } \\
\text { data. Clinical } \\
\text { Trial. }\end{array}$ & $\begin{array}{l}\text { Three } \\
\text { hospitals } \\
\text { in North } \\
\text { Carolina: } \\
\text { Wake } \\
\text { Forest } \\
\text { Baptist } \\
\text { Medical } \\
\text { Center, } \\
\text { with } \\
114,000 \\
\text { annual } \\
\text { ED visits; } \\
\text { Davie } \\
\text { Medical } \\
\text { Center, } \\
\text { with } \\
12,000 \\
\text { annual } \\
\text { ED visits; }\end{array}$ & $\begin{array}{l}\text { Safety in } \\
\text { Implementat } \\
\text { ion of } \\
\text { HEART } \\
\text { pathway for } \\
\text { CP in the } \\
\text { ED }\end{array}$ & $\begin{array}{l}\text { Pre- and } \\
\text { post- } \\
\text { implementa } \\
\text { tion } \\
\text { cohorts; } \\
\text { In } 24 \\
\text { months: } \\
8474 \\
\text { patients; } \\
53.6 \% \\
\text { female, } \\
28.6 \% \\
\text { black, and } \\
17.5 \% \\
\text { uninsured } \\
\text { with a } \\
\text { median age } \\
\text { of } 54 \text { years. } \\
30.7 \% \text { low } \\
\text { risk. }\end{array}$ & None & $\begin{array}{l}\text { HEART } \\
\text { Pathway } \\
\text { identified } \\
\text { more } \\
\text { patients } \\
\text { with MI } \\
\text { during } \\
\text { index visit } \\
\text { compared to } \\
\text { before } \\
\text { implementat } \\
\text { ion cohort. } \\
\text { Decreased } \\
\text { admissions } \\
\text { \& death \& } \\
\text { MI rates to } \\
<1 \% \text {. }\end{array}$ & $\begin{array}{l}\text { Level I, A } \\
\text { Robust } \\
\text { study with } \\
\text { definitive } \\
\text { clinical } \\
\text { improveme } \\
\text { nts with CP } \\
\text { patient } \\
\text { outcomes. }\end{array}$ \\
\hline
\end{tabular}




\begin{tabular}{|c|c|c|c|c|c|c|c|}
\hline & & $\begin{array}{l}\text { and } \\
\text { Lexington } \\
\text { Medical } \\
\text { Center, } \\
\text { with } \\
37,000 \\
\text { annual } \\
\text { ED visits. } \\
\text { Target } \\
\text { populatio } \\
\text { n ED } \\
\text { patients } \\
\text { ( } \geq 21 \text { yrs. } \\
\text { of age) } \\
\text { with } \\
\text { possible } \\
\text { ACS but } \\
\text { without } \\
\text { ST- } \\
\text { elevation } \\
\text { on EKG. }\end{array}$ & & $\begin{array}{l}0.4 \% \text { death } \\
\text { or MI after } \\
30 \text { days. } \\
6 \% \\
\text { reduction } \\
\text { in } \\
\text { hospitalize } \\
\text { d patients } \\
\text { after } 30 \\
\text { days, post- } \\
\text { implementa } \\
\text { tion. } \\
\text { (55.6\% } \\
\text { versus } \\
61.6 \% \text {; } \\
\text { adjusted } \\
\text { odds ratio, } \\
0.79 ; 95 \% \\
\text { CI, } 0.71- \\
0.87) \text {. }\end{array}$ & & & \\
\hline $\begin{array}{l}\text { Rachuba, S., } \\
\text { Salmon, A., Zhelev, } \\
\text { Z., \& Pitt, M. } \\
\text { (2018). Redesigning } \\
\text { the diagnostic } \\
\text { pathway for chest } \\
\text { pain patients in } \\
\text { emergency } \\
\text { departments. Health } \\
\text { care management } \\
\text { science, 21(2), 177- } \\
\text { 191. }\end{array}$ & $\begin{array}{l}\text { Discrete- } \\
\text { event } \\
\text { simulation } \\
\text { (DES) }\end{array}$ & $\begin{array}{l}\text { A total } \\
\text { number of } \\
\text { over } \\
8,200 \\
\text { patient } \\
\text { episodes } \\
\text { over a } \\
\text { period of } \\
12 \text { months } \\
\text { included } \\
\text { in the } \\
\text { analysis. } \\
\text { Using } \\
\text { NICE } \\
\text { protocols } \\
\text { for CP } \\
\text { patients. }\end{array}$ & $\begin{array}{l}\text { Impacts of } \\
\text { NICE on } \\
\text { LOS in the } \\
\text { ED, LOS in } \\
\text { CDU, and } \\
\text { number of } \\
\text { discharges } \\
\text { vs. } \\
\text { admissions. }\end{array}$ & $\begin{array}{l}\text { Changes in } \\
\text { troponin } \\
\text { levels of } \\
\text { patients } \\
\text { with } \\
\text { STEMI vs. } \\
\text { NSTEMI; } \\
\text { and cardiac } \\
\text { vs. non- } \\
\text { cardiac CP. }\end{array}$ & None & $\begin{array}{l}\text { Decreased } \\
\text { rate of } \\
\text { admissions, } \\
\text { LOS and } \\
\text { time to } \\
\text { discharge } \\
\text { from } 6 \\
\text { hours to } 2 \\
\text { hours. }\end{array}$ & $\begin{array}{l}\text { Level III, A } \\
\text { Scenario- } \\
\text { based } \\
\text { simulations } \\
\text { with } \\
\text { supporting } \\
\text { scientific } \\
\text { evidence }\end{array}$ \\
\hline $\begin{array}{l}\text { Than, M. P., } \\
\text { Pickering, J. W., } \\
\text { Dryden, J. M., Lord, } \\
\text { S. J., Aitken, S. A., } \\
\text { Aldous, S. J., ... \& } \\
\text { Chapman, L. R. } \\
\text { (2018). ICare-ACS } \\
\text { (Improving Care } \\
\text { Processes for } \\
\text { patients with } \\
\text { suspected acute } \\
\text { coronary syndrome) } \\
\text { A study of cross- } \\
\text { system } \\
\text { implementation of a } \\
\text { national clinical } \\
\text { pathway. Circulatio } \\
n, \text { 137(4), 354-363 }\end{array}$ & $\begin{array}{l}\text { Multicenter, } \\
\text { pragmatic, } \\
\text { stepped- } \\
\text { wedge } \\
\text { before- and- } \\
\text { after } \\
\text { implementati } \\
\text { on study; } \\
\text { Using EMR }\end{array}$ & $\begin{array}{l}\text { Seven } \\
\text { hospitals } \\
\text { of varied } \\
\text { size and } \\
\text { populatio } \\
\mathrm{n} \\
\text { demograp } \\
\text { hics; } \\
\text { controlled } \\
\text { period of } \\
6 \text { months } \\
\text { pre } \\
\text { implemen } \\
\text { tation, } \\
\text { involving } \\
\text { standard } \\
\text { practices } \\
\text { for ACS. }\end{array}$ & $\begin{array}{l}\text { Participating } \\
\text { hospitals } \\
\text { used either } \\
\text { contemporar } \\
\text { y or high- } \\
\text { sensitivity } \\
\text { troponin } \\
\text { assays and } \\
\text { accelerated } \\
\text { protocols } \\
\text { with either } \\
\text { score or the } \\
\text { Emergency } \\
\text { Department } \\
\text { Assessment } \\
\text { of Chest } \\
\text { pain Score. }\end{array}$ & $\begin{array}{l}\text { Primary } \\
\text { outcome } \\
\text { between } \\
\text { control and } \\
\text { interventio } \\
\mathrm{n} \text { was } \\
\text { compared } \\
\text { with a } \\
\text { Cochran- } \\
\text { Mantel- } \\
\text { Haenszel } \\
\text { test for } \\
\text { stratified } \\
\text { data and } \\
\text { expressed } \\
\text { as an odds } \\
\text { ratio. } \\
\text { Compariso } \\
\text { ns of length } \\
\text { of hospital } \\
\text { stay were }\end{array}$ & None & $\begin{array}{l}\text { Implementi } \\
\text { ng clinical } \\
\text { pathways } \\
\text { (protocols), } \\
\text { for ACS } \\
\text { patients in } \\
\text { the ED, can } \\
\text { safely } \\
\text { reduce LOS. } \\
\text { Safe, early } \\
\text { discharges } \\
\text { occurred } \\
\text { using } \\
\text { protocols. }\end{array}$ & $\begin{array}{l}\text { Level II, A } \\
\text { Large study } \\
\text { over } \\
\text { numerous } \\
\text { facilities } \\
\text { and size. }\end{array}$ \\
\hline
\end{tabular}




\begin{tabular}{|c|c|c|c|c|c|c|c|}
\hline & & & & $\begin{array}{l}\text { by the } \\
\text { Mann- } \\
\text { Whitney } \\
\text { test. All } \\
\text { statistical } \\
\text { calculations } \\
\text { were } \\
\text { performed } \\
\text { in R 3.2.4 }\end{array}$ & & & \\
\hline $\begin{array}{l}\text { Yau, A. A., } \\
\text { Nguyendo, L. T., } \\
\text { Lockett, L. L., \& } \\
\text { Michaud, E. (2017). } \\
\text { The HEART } \\
\text { Pathway and } \\
\text { hospital cost } \\
\text { savings. Critical } \\
\text { pathways in } \\
\text { cardiology, 16(4), } \\
126\end{array}$ & $\begin{array}{l}\text { Prospective } \\
\text { cohort study; } \\
\text { proof-of- } \\
\text { concept } \\
\text { study. }\end{array}$ & $\begin{array}{l}\text { 425-bed } \\
\text { facility } \\
\text { with 57- } \\
\text { bed ED; } \\
\text { attached } \\
\text { Internal } \\
\text { Medicine } \\
\& \\
\text { Cardiolog } \\
\text { y clinics. }\end{array}$ & $\begin{array}{l}\text { Evaluation } \\
\text { of } \\
\text { accelerated } \\
\text { vs. standard } \\
\text { treatment } \\
\text { pathways for } \\
\text { CP patients } \\
\text { in the ED to } \\
\text { reduce costs. }\end{array}$ & $\begin{array}{l}\text { No } \\
\text { statistical } \\
\text { calculations } \\
\text {; only raw } \\
\text { financial } \\
\text { data for } \\
\text { comparison } \\
\text { Demonstrat } \\
\text { es how } \\
\text { education } \\
\text { and use of } \\
\text { HEART } \\
\text { protocol by } \\
\text { the ED can } \\
\text { reduce } \\
\text { hospitalizat } \\
\text { ion of low } \\
\text { risk CP } \\
\text { patients } \\
\text { and result } \\
\text { in }>20 \% \\
\text { savings. }\end{array}$ & None & $\begin{array}{l}\text { Admissions } \\
\text { decreased } \\
27 \%, \\
\text { resulting in } \\
328 \text { days of } \\
\text { hospitalized } \\
\text { patient } \\
\text { savings = } \\
\$ 904,952 \\
\text { over } 1 \text { year. } \\
\text { Corresponds } \\
\text { to } 22 \% \\
\text { decreased } \\
\text { inpatient } \\
\text { expenses; } \\
\text { average } \\
\text { daily } \\
\text { hospital day } \\
=\$ 2759 .\end{array}$ & $\begin{array}{l}\text { Level V, A } \\
\text { Provides } \\
\text { only local } \\
\text { financial } \\
\text { assessment } \\
\text { of HEART } \\
\text { accelerated } \\
\text { protocols. }\end{array}$ \\
\hline $\begin{array}{l}\text { Yiadom, M. Y. A., } \\
\text { Baugh, C. W., } \\
\text { McWade, C. M., } \\
\text { Liu, X., Song, K. J., } \\
\text { Patterson, B. W., ... } \\
\text { \& Wang, T. J. } \\
\text { (2017). } \\
\text { Performance of } \\
\text { emergency } \\
\text { department } \\
\text { screening criteria } \\
\text { for an early ECG to } \\
\text { identify ST-segment } \\
\text { elevation } \\
\text { myocardial } \\
\text { infarction. Journal } \\
\text { of the American } \\
\text { Heart } \\
\text { Association, 6(3), } \\
\text { e003528. }\end{array}$ & $\begin{array}{l}\text { Prospective } \\
\text { historical } \\
\text { cohort study }\end{array}$ & $\begin{array}{l}\text { Seven } \\
\text { EDs with } \\
\text { geographi } \\
\text { cal } \\
\text { diversity } \\
\text { and } \\
\text { populatio } \\
\text { n density. } \\
\text { Used to } \\
\text { reduce } \\
\text { spectrum } \\
\text { bias from } \\
\text { regional } \\
\text { practice } \\
\text { variation. }\end{array}$ & $\begin{array}{l}\text { Evaluate } \\
\text { patient- } \\
\text { oriented } \\
\text { outcomes } \\
\text { associated } \\
\text { with } \\
\text { screening } \\
\text { performance } \\
\text { variation for } \\
\text { primarily } \\
\text { ED-screened } \\
\text { STEMI } \\
\text { patients and } \\
\text { the impact } \\
\text { of a false- } \\
\text { negative } \\
\text { screen on } \\
\text { myocardial } \\
\text { ischemia } \\
\text { time. }\end{array}$ & $\begin{array}{l}\text { Spearman } \\
\text { rank } \\
\text { correlation } \\
\text { coefficient } \\
\text { calculations } \\
\text { between } \\
\text { continuous } \\
\text { factors and } \\
\text { the MCR as } \\
\text { well as } \\
\text { other } \\
\text { STEMI } \\
\text { screening } \\
\text { performanc } \\
\text { e measures. } \\
\text { The } \\
\text { Kruskal- } \\
\text { Wallis test } \\
\text { was used to } \\
\text { compare } \\
\text { STEMI } \\
\text { screening } \\
\text { performanc } \\
\text { e across } \\
\text { levels of } \\
\text { categorical } \\
\text { factors. } \\
472,166\end{array}$ & None & $\begin{array}{l}\text { A } 29.2 \% \\
\text { difference } \\
\text { in MCR } \\
\text { rates } \\
\text { reflects } \\
\text { room for } \\
\text { improvemen } \\
\mathrm{t} \text { in STEMI } \\
\text { identificatio } \\
\mathrm{n} \text { in ED } \\
\text { patients. }\end{array}$ & $\begin{array}{l}\text { Level I, A } \\
\text { Robust } \\
\text { study } \\
\text { involving } \\
\text { multiple } \\
\text { medical } \\
\text { centers } \\
\text { with } \\
\text { different } \\
\text { populations } \\
\text { and } \\
\text { geographic } \\
\text { al regions. }\end{array}$ \\
\hline
\end{tabular}




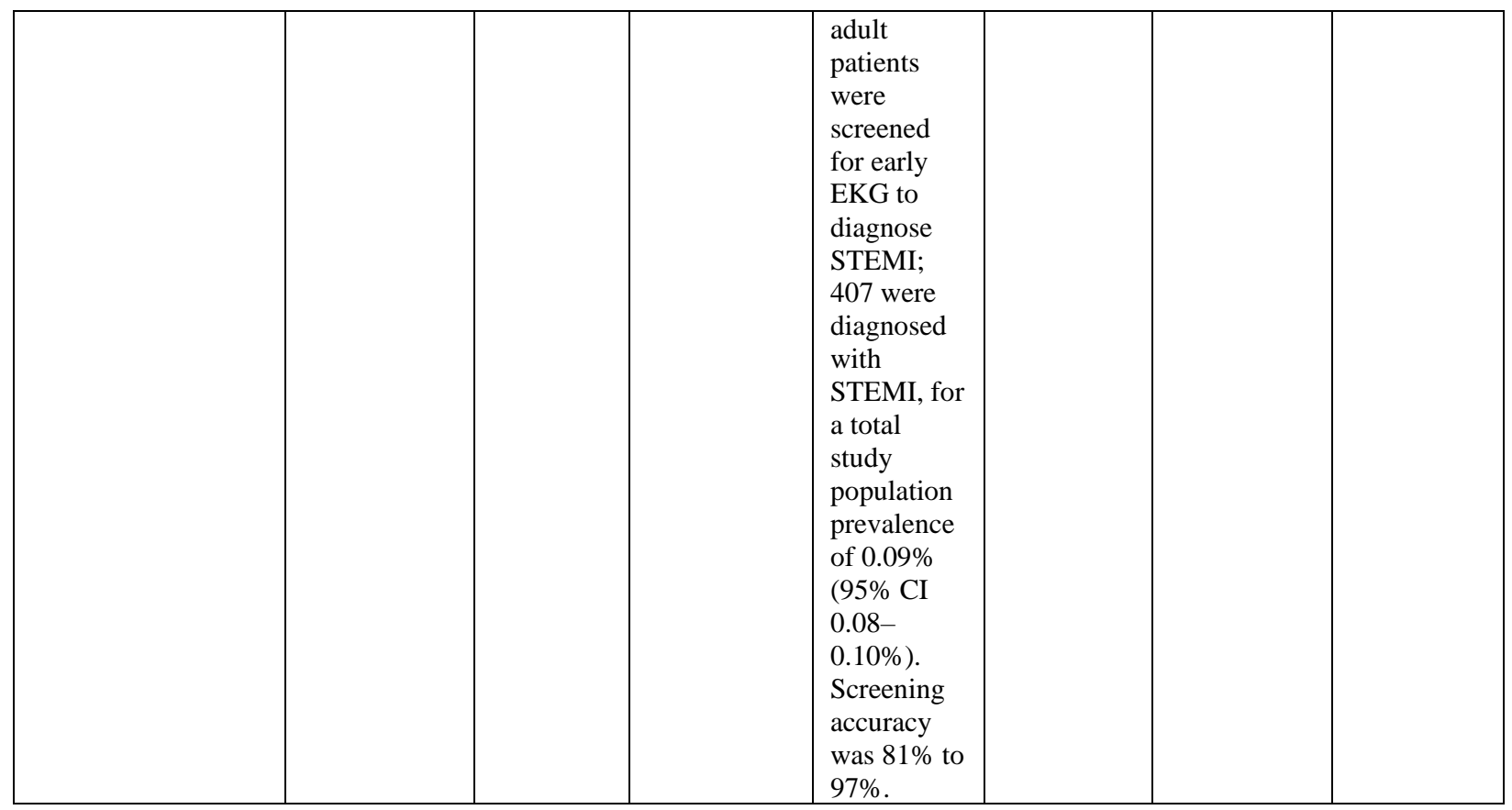

Legend:

ACS - acute coronary syndrome

ADP - Accelerated Diagnostic Protocol

AMI - acute myocardial infarction

CDU - Clinical Decision Unit

$\mathrm{CP}$ - chest pain

EMR - Electronic Medical Record

HEART - History, EKG, Age, Risk factors, Troponin

IMPACT - IMProved Assessment of Chest Pain Trial

MCR - Missed Case Rate

NICE - National Institute for Health and Care Excellence

NSTEMI - non-ST segment elevation myocardial infraction

SCAMP - Standardized Clinical Assessment and Management Plan

SO - standing orders

SRQR - Standards for the Reporting of Qualitative Research

STEMI - ST elevation myocardial infarction

TIMI - Thrombolysis in Myocardial Infraction 


\section{Appendix B}

\section{Summary of Systematic Reviews (SR)}

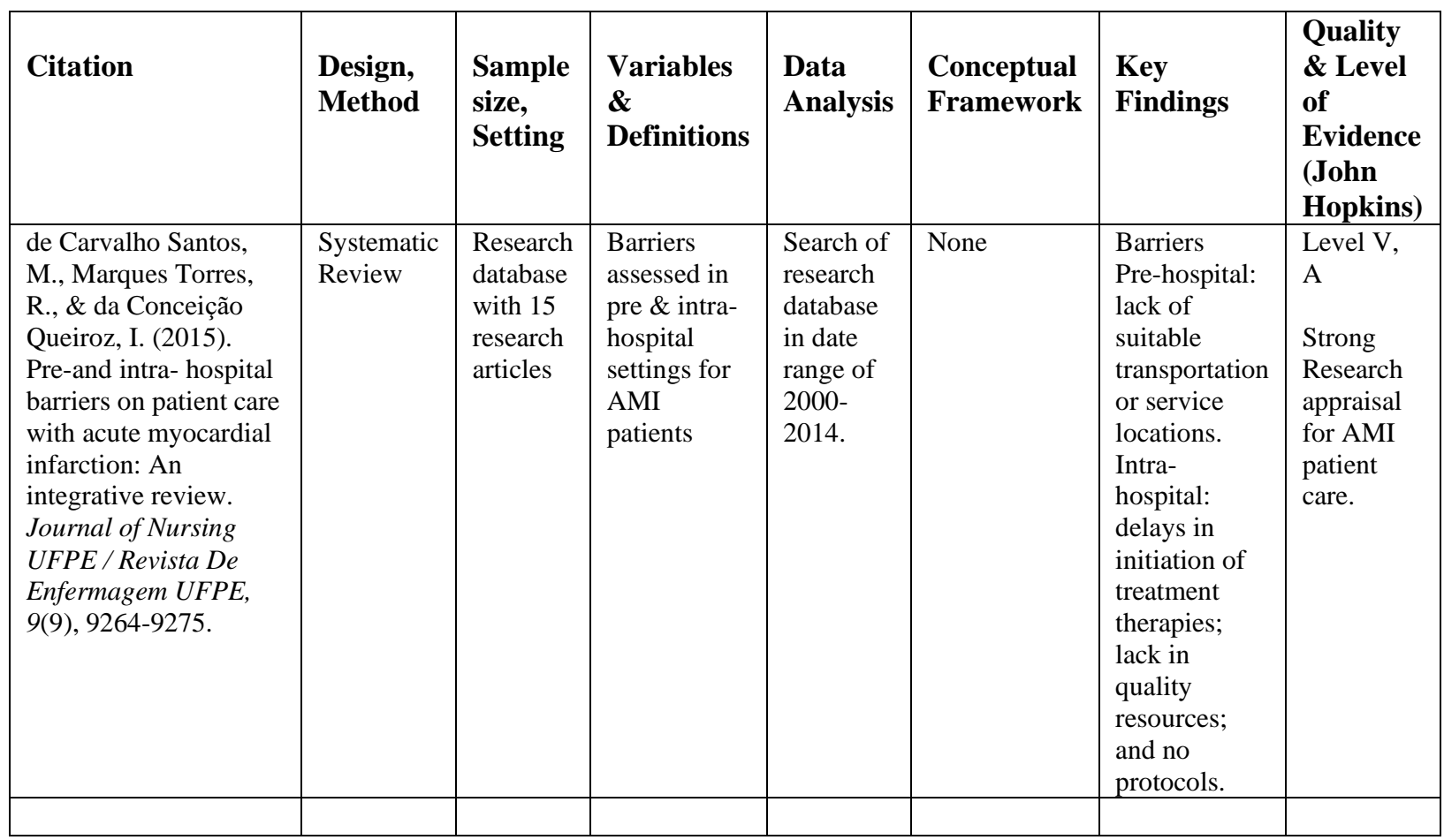

\section{Legend:}

AMI - acute myocardial infarction 


\section{Appendix C}

\section{Timeline for Project}

\begin{tabular}{|c|c|c|c|c|c|c|c|c|c|c|c|c|c|c|c|}
\hline \multirow[b]{2}{*}{ Activity } & \multicolumn{7}{|c|}{ Summer NUR7802 Practicum } & \multicolumn{8}{|c|}{ Fall NUR7803 Practicum } \\
\hline & 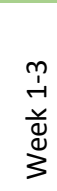 & 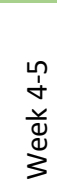 & $\begin{array}{l}\hat{1} \\
\frac{1}{0} \\
\stackrel{0}{3}\end{array}$ & 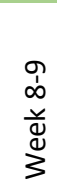 & 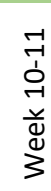 & 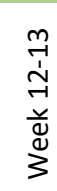 & 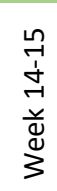 & 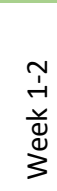 & 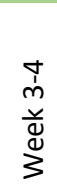 & 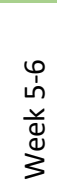 & 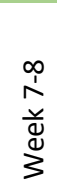 & 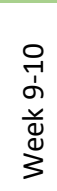 & 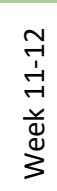 & 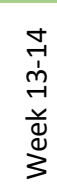 & $\begin{array}{l}\stackrel{n}{-1} \\
\stackrel{2}{d} \\
\stackrel{d}{3}\end{array}$ \\
\hline $\begin{array}{l}\text { Guidance and meeting with } \\
\text { Preceptor }\end{array}$ & $x$ & $x$ & $x$ & $x$ & $x$ & $x$ & $x$ & $x$ & $x$ & $x$ & $x$ & $x$ & $x$ & $x$ & $x$ \\
\hline ED Project teamwork & $x$ & $x$ & & $x$ & & $x$ & $x$ & $x$ & & $x$ & & $x$ & & $x$ & $x$ \\
\hline $\begin{array}{l}\text { Project proposal to EPRC for } \\
\text { approval }\end{array}$ & $x$ & & & & & & & & & & & & & & \\
\hline $\begin{array}{l}\text { USA EPRC proposal to } \\
\text { CNVAMC for approval }\end{array}$ & & $x$ & & & & & & & & & & & & & \\
\hline $\begin{array}{l}\text { Choose Key } \\
\text { Stakeholders/Team for ED } \\
\text { project }\end{array}$ & & & $x$ & & & & & & & & & & & & \\
\hline $\begin{array}{l}\text { Clinical Application } \\
\text { Coordinator (IT) to enter } \\
\text { approved NIP order set into } \\
\text { CPRS \& evaluation of proper } \\
\text { function in a testing } \\
\text { environment prior to go-live. }\end{array}$ & & & $x$ & & & & & & & & & & & & \\
\hline $\begin{array}{l}\text { Present ED CP NIP for ED } \\
\text { Team approval }\end{array}$ & & & $x$ & & & & & & & & & & & & \\
\hline $\begin{array}{l}\text { Education roll-out to } \\
\text { Champion clinical staff / } \\
\text { Providers }\end{array}$ & & & & $x$ & & & & & & & & & & & \\
\hline $\begin{array}{l}\text { ED clinical staff education / } \\
\text { Q\&A sessions }\end{array}$ & & & & $x$ & & & & & & & & & & & \\
\hline Go live with CP NIP in the ED & & & & $x$ & & & & & & & & & & & \\
\hline $\begin{array}{l}\text { Collect retrospective data for } \\
\text { CP patients }\end{array}$ & & & & $x$ & $x$ & & & & & & & & & & \\
\hline $\begin{array}{l}\text { Using PDSA process, data } \\
\text { review / adjust NIP as } \\
\text { needed }\end{array}$ & & & & $x$ & $x$ & $x$ & & & & & & & & & \\
\hline $\begin{array}{l}\text { Ongoing data collection: LOS } \\
\text { after starting use of CP NIP in } \\
\text { ED }\end{array}$ & & & & & $x$ & $x$ & $x$ & $x$ & $x$ & & & & & & \\
\hline $\begin{array}{l}\text { Analysis with finalized data } \\
\text { collection }\end{array}$ & & & & & & & & & & $x$ & $x$ & & & & \\
\hline $\begin{array}{l}\text { Comparison of Pre \& Post CP } \\
\text { NIP use }\end{array}$ & & & & & & & & & & & $x$ & & & & \\
\hline $\begin{array}{l}\text { Finalize data \& prepare for } \\
\text { project conclusion }\end{array}$ & & & & & & & & & & & $x$ & & & & \\
\hline $\begin{array}{l}\text { Ongoing meeting \& } \\
\text { discussion with project team } \\
\text { with scheduled updates }\end{array}$ & & $x$ & & $x$ & & $x$ & & $x$ & & $x$ & & $x$ & & $x$ & $x$ \\
\hline
\end{tabular}




\section{Appendix D}

\section{Computer-based Chest Pain Nurse-initiated Protocol Order Set}

Chest Pain: Symptoms may include chest pain ranging from mild to severe, described as aching, sharp, tingling, burning, heavy, squeezing, heartburn, or tight. Veterans may complain of lightheadedness, palpitations, diaphoresis, shortness of breath, nausea, indigestion, anxiety, restlessness, denial, or depression.

a. Lab orders

- I-Stat TROPONIN if positive, lab TROPONIN

- CMP

- CBC with diff

- $\mathrm{CKMB} / \mathrm{CK}$

- Pregnancy HCG Urine POC test (females of childbearing age)

b. Nursing orders

- EKG within 10 minutes of arrival and given directly to MD

- Supplemental Oxygen as needed to keep saturation $>92 \%$

- If positive troponin or suspicious EKG, bed immediately

- Initiate peripheral IV saline lock.

c. Radiology orders

- STAT CXR 1 view (portable) if unstable

- STAT CXR 2 view PA \& LAT if stable 


\section{Appendix E}

\section{Data Collection Tool}

\begin{tabular}{|c|c|c|c|c|c|c|c|c|c|c|c|}
\hline Pre/Post & Date & Patient \# & \begin{tabular}{|l|}
$\begin{array}{l}\text { Registration } \\
\text { Time }\end{array}$ \\
\end{tabular} & \begin{tabular}{|l} 
Triage Time \\
(Nurse)
\end{tabular} & \begin{tabular}{|l|} 
NIP Initiated \\
Time
\end{tabular} & EKG time & \begin{tabular}{|l} 
Seen by \\
Provider
\end{tabular} & \begin{tabular}{|l} 
Discharge \\
Time
\end{tabular} & Time to NIP & \begin{tabular}{|l} 
LOS \\
Calculated
\end{tabular} & Notes \\
\hline Example & $1 / 1$ & 1 & \begin{tabular}{|r|}
$13: 30$ \\
\end{tabular} & \begin{tabular}{|r|}
$13: 33$ \\
\end{tabular} & \begin{tabular}{|r|}
$13: 40$ \\
\end{tabular} & $\begin{array}{r}13: 56 \\
\end{array}$ & \begin{tabular}{|r|}
$15: 32$ \\
\end{tabular} & \begin{tabular}{|r|}
$18: 24$ \\
\end{tabular} & $\begin{array}{r}0: 07 \\
\end{array}$ & $\begin{array}{r}4: 54 \\
\end{array}$ & \\
\hline Pre & & 1 & & & & & & & $0: 00$ & $0: 00$ & \\
\hline Pre & & 2 & & & & & & & $0: 00$ & $0: 00$ & \\
\hline Pre & & 3 & & & & & & & $0: 00$ & $0: 00$ & \\
\hline Pre & & 4 & & & & & & & $0: 00$ & $0: 00$ & \\
\hline Pre & & 5 & & & & & & & $0: 00$ & $0: 00$ & \\
\hline Pre & & 6 & & & & & & & $0: 00$ & $0: 00$ & \\
\hline Pre & & 7 & & & & & & & $0: 00$ & $0: 00$ & \\
\hline Pre & & 8 & & & & & & & $0: 00$ & $0: 00$ & \\
\hline Pre & & 9 & & & & & & & $0: 00$ & $0: 00$ & \\
\hline Pre & & 10 & & & & & & & $0: 00$ & $0: 00$ & \\
\hline Pre & & 11 & & & & & & & $0: 00$ & $0: 00$ & \\
\hline Pre & & 12 & & & & & & & $0: 00$ & $0: 00$ & \\
\hline Pre & & 13 & & & & & & & $0: 00$ & $0: 00$ & \\
\hline Pre & & 14 & & & & & & & $0: 00$ & $0: 00$ & \\
\hline Pre & & 15 & & & & & & & $0: 00$ & $0: 00$ & \\
\hline Pre & & 16 & & & & & & & $0: 00$ & $0: 00$ & \\
\hline Pre & & 17 & & & & & & & $0: 00$ & $0: 00$ & \\
\hline Pre & & 18 & & & & & & & $0: 00$ & $0: 00$ & \\
\hline Pre & & 19 & & & & & & & $0: 00$ & $0: 00$ & \\
\hline Pre & & 20 & & & & & & & $0: 00$ & $0: 00$ & \\
\hline Pre & & 21 & & & & & & & $0: 00$ & $0: 00$ & \\
\hline Pre & & 22 & & & & & & & $0: 00$ & $0: 00$ & \\
\hline Pre & & 23 & & & & & & & $0: 00$ & $0: 00$ & \\
\hline Pre & & 24 & & & & & & & $0: 00$ & $0: 00$ & \\
\hline Pre & & 25 & & & & & & & $0: 00$ & $0: 00$ & \\
\hline Pre & & 26 & & & & & & & $0: 00$ & $0: 00$ & \\
\hline Pre & & 27 & & & & & & & $0: 00$ & $0: 00$ & \\
\hline Pre & & 28 & & & & & & & $0: 00$ & $0: 00$ & \\
\hline Pre & & 29 & & & & & & & $0: 00$ & $0: 00$ & \\
\hline Pre & & 30 & & & & & & & $0: 00$ & 0:00 & \\
\hline Post & & 31 & & & & & & & $0: 00$ & $0: 00$ & \\
\hline Post & & 32 & & & & & & & $0: 00$ & 0:00 & \\
\hline Post & & 33 & & & & & & & $0: 00$ & $0: 00$ & \\
\hline Post & & 34 & & & & & & & $0: 00$ & 0:00 & \\
\hline Post & & 35 & & & & & & & $0: 00$ & $0: 00$ & \\
\hline Post & & 36 & & & & & & & $0: 00$ & $0: 00$ & \\
\hline Post & & 37 & & & & & & & $0: 00$ & $0: 00$ & \\
\hline Post & & 38 & & & & & & & $0: 00$ & 0:00 & \\
\hline Post & & 39 & & & & & & & $0: 00$ & $0: 00$ & \\
\hline Post & & 40 & & & & & & & $0: 00$ & $0: 00$ & \\
\hline Post & & 41 & & & & & & & $0: 00$ & $0: 00$ & \\
\hline Post & & 42 & & & & & & & $0: 00$ & $0: 00$ & \\
\hline Post & & 43 & & & & & & & $0: 00$ & $0: 00$ & \\
\hline Post & & 44 & & & & & & & $0: 00$ & $0: 00$ & \\
\hline Post & & 45 & & & & & & & $0: 00$ & $0: 00$ & \\
\hline Post & & 46 & & & & & & & $0: 00$ & $0: 00$ & \\
\hline Post & & 47 & & & & & & & $0: 00$ & $0: 00$ & \\
\hline Post & & 48 & & & & & & & $0: 00$ & $0: 00$ & \\
\hline Post & & 49 & & & & & & & $0: 00$ & $0: 00$ & \\
\hline Post & & 50 & & & & & & & $0: 00$ & $0: 00$ & \\
\hline Post & & 51 & & & & & & & $0: 00$ & $0: 00$ & \\
\hline Post & & 52 & & & & & & & $0: 00$ & $0: 00$ & \\
\hline Post & & 53 & & & & & & & $0: 00$ & $0: 00$ & \\
\hline Post & & 54 & & & & & & & $0: 00$ & $0: 00$ & \\
\hline Post & & 55 & & & & & & & $0: 00$ & $0: 00$ & \\
\hline Post & & 56 & & & & & & & $0: 00$ & $0: 00$ & \\
\hline Post & & 57 & & & & & & & $0: 00$ & $0: 00$ & \\
\hline Post & & 58 & & & & & & & $0: 00$ & $0: 00$ & \\
\hline Post & & 59 & & & & & & & $0: 00$ & $0: 00$ & \\
\hline Post & & 60 & & & & & & & $0: 00$ & $0: 00$ & \\
\hline
\end{tabular}

